s...

09

x 3

B2 


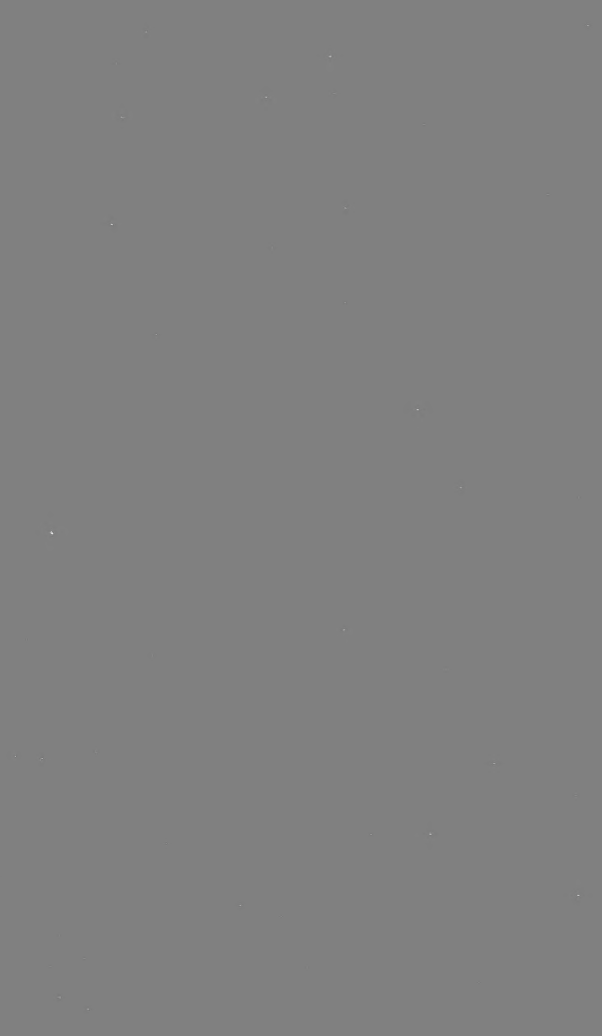




\section{Tbe Univergity of cbicago}

FOUNDED BY JOHN D. ROCKEFELLEK

\section{THE ETHNO-BOTANY OF THE COAHULLA INDIANS OF SOUTHERN CALIFORNIA}

A DISSERTATION SUBMITTED TO THE EACULTIES OF THE GRADUATE SCHOOLS OF ARTS, LITERATUKE, AND SCIFNCE, IN CANDIDACY FOR THE DFGREE OF DOCTOR OF PHILOSOPHY

(LEPARTMENT OF ANTHROPOLOGY)

BY

DAVID PKESCOTT BARROWS

Ebe University of Cbicago Dress 



\title{
THE ETHNO-BOTANY OF THE COAHUILLA INDIANS OF SOUTHERN CALIF(ORNIA
}

A DISSERTATION SUBMITTED TO THE FACUI,TIES OF THE GRADUATE SCHOOLS OF ARTS, LITERATURE, AND SCIENCE', IN CANEIDACY FOP.

THE DEGREE OF DOCTOR OF H HTEOSOFHY'

(DEPARTMENT OF ANTHROPOLOGY)

BY

DAVID PRESCOTT, BARROWS

\author{
CHICAGO
}

Tbe University of Cbicago Dress

1900 


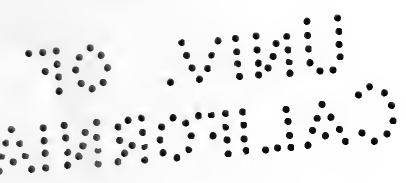




\section{THIS MONOGRAPH}

IS INSCRIBED AS A MEMORIAL OF MY FATHER,

THOMAS' BARROWS

(OBIIT JANUARY I2, r898),

AND OF MY MOTHER,

ELLA COLE BARROWS

(OBIT SEPTEMBeR $\mathbf{1 8}, \mathbf{1 8 9 8}$ ).

$$
\therefore \div \div \div \div
$$




\section{FOREWORD}

THIS monograph was accepted in candidacy for the degree of doctor of philosophy at the University of Chicago in June, 1897 .

Further field-research immediately following made necessary a revision before publication, and this latter work has been long, but unavoidably, delayed.

I wish to acknowledge my great obligations to Dr. W. L. Jepson, of the University of California, for his services in identifying my botanical specimens. Many of my collections were hastily gathered, and, without flowers or sufficient foliage, could be determined only by one especially trained in the desert flora of California.

It would be a great pleasure to mention by name the many Coahuilla friends whose interest and assistance have made this study possible. One of them, my friend and inmate of my home, Martin Costo, has read nearly the entire manuscript and made numerous corrections. The proofs have been read by Dr. Merton L. Miller, of the University of Chicago, and the entire essay has received the benefit of his attention.

It is fitting, also, that I should acknowledge the large part that has been taken in the preparation of this essay by my wife, Anna Spencer Nichols Barrows. Mrs. Barrows accompanied me when much of this material was secured, and her coöperation has been invaluable at every point of preparation.

Manila, P. I., December, 1900.

D. P. B. 


\section{TABLE OF CON'TENTS}

INTRODUCTION

I. Recent Studies in Ethno-Botany . . . . . . . . . . . . . . 7

2. Plan of this Monograph . . . . . . . . . . . . . . . . . 7

3. Orthography of Coahuilla Words . . . . . . . . . . . . 8

\section{Chapter I. Linguistic and Tribal Affinities of the Coahullla} INDIANS . . . . . . . . . . . • • • . . . 9

4. Past Study of the California Tribes . . . . . . . . . . . . . 9

5. The Franciscan Missions . . . . . . . . . . . . . . . . . 9

6. Tribes of Southern California . . . . . . . . . . . . . . 10

7. Review of the Linguistic Material Available for Classifying these Indians II

8. Conclusions as to Former Distribution, Migrations, and Linguistic Connections of the Coahuillas . . . . . . . . . . . . . . $2 \mathrm{I}$

9. Affiliation of the Coahuillas with the Desert Tribes . . . . . . 23

Chapter II. The Habitat of the Coahulllas . . . . . . 25

I. Geography of the American Desert . . . . . . . . . . . . . 25

I I. The Cabeson Valley and Surrounding Ranges . . . . . . . . . 26

12. Peculiarities of Desert Life . . . . . . . . . . . . . . . 28

I3. The Desert of the Colorado . . . . . . . . . . . . . . . 29

I 4. The Flora of the Colorado Desert . . . . . . . . . . . . . 3 I

15. Homes on the Desert and Mountain . . . . . . . . . . . . . 32

I6. The Coyote Cañon and Coahuilla Valley . . . . . . . . . . . 34

Chapter III. Houses And House-Bullding . . . . . . . 35

17. The Coahuilla Rancheria . . . . . . . . . . . . . . . 35

18. The Typical Jacal . . . . . . . . . . . . . . . 36 '

19. Naterials Utilized for Houses in Various Villages . . . . . . . 38

20. Evolution of the Jacal . . . . . . . . . . . . . . . 38 '

2 I. Feast Booths . . . . . . . . . . . . . . . . . . . . $39^{\circ}$

22. Furnishings of a llome . . . . . . . . . . . . . . . . . 40

Chapter IV. Baskets and Basket-Making. . . . . . . 40

23. Character and Description of Coahuilla Baskets . . . . . . . . 40

24. Materials Used in Basket Manufacture . . . . . . . . . . . . 4 I

25. Method of Weaving . . . . . . . . . . . . . . . . . . 43

26. Different Shapes and Uses of Baskets . . . . . . . . . . . . 44 
Chapter V. Plant Materials Used in Manufactures and Arts 45

27. The Question of Pottery . . . . . . . . . . . . . . 45

28. Woven Articles . . . . . . . . . . . . . . . . . . . . 47

29. Gums and Glues . . . . . . . . . . . . . . . . . 48

30. Soap Plants . . . . . . . . . . . . . . . . . . 48

31. Tattooing . . . . . . . . . . . . . . . . . . . . . . 49

32. Baby-Boards and Hammocks . . . . . . . . . . . . . . 49

33. Bow, Arrow, and Throwing Stick . . . . . . . . . . . . . 49

Chapter Vi. The Gathering, Preparation, and Storing of Foods 50

34. The Discovery of Food Plants . . . . . . . . . . . . 50

35. Harvesting Implements . . . . . . . . . . . . . . . 5 I

36. The Leaching Basket . . . . . . . . . . . . . . . . 52

37. Granaries . . . . . . . . . . . . . . . . . 52

38. Milling . . . . . . . . . . . . . . . . . 53

39. Cooking . . . . . . . . . . . . . . . . . . . 54

Chapter Vil. Food Plants of the Coahuilla Indians . . . 54

40. Variety of Food Products . . . . . . . . . . . . . . . . 54

4I. Staples of the Desert Plain … . . . . . . . . . . . . 55

42. Food Plants of the Desert Hills . . . . . . . . . . . . . 57

43. Food-Yielding Trees of the Desert Mountains . . . . . . . . 60

44. Acorns and Piñones . . . . . . . . . . . . . . . . . . 6r

45. Fruits and Berries . . . . . . . . . . . . . . . 63

46. Seeds Used for Food . . . . . . . . . . . . . . . . . . 64

47. Edible Flowers and Buds . . . . . . . . . . . . . 65

48. The Cacti . . . . . . . . . . . . . . . . . . . . 67

49. Abundance of the Coahuilla Food Supply . . . . . . . . . . . 69

50. Cultivated Plants. Grain Threshing . . . . . . . . . . . 70

51. Source of the Knowledge of Agriculture . . . . . . . . . . . 71

Chapter Vili. Drinks, Narcotics, And Medicines . . . . . 73

52. Beverages and Teas . . . . . . . . . . . . . . . . . 73

53. Tobacco and Intoxicants . . . . . . . . . . . . . . . . 74

54. The Coahuilla Shaman . . . . . . . . . . . . . 75

55. The Temescal . . . . . . . . . . . . . . . . . . . 76

56. Plant Remedies . . . . . . . . . . . . . . . . . . . 77

57. Remedies for Live Stock . . . . . . . . . . . . . . . . 79

58. A Final Estimate of the Culture of the Coahuillas . . . . . . . . 80 


\section{INTRODUCTION.}

I. The study of the ethno-botany of the American Indians has lately been receiving considerable attention at the hands of the American scientists. In March, I890, Dr. J. W. Harshberger published a short paper on the "Purposes of Ethno-botany," suggested by the study of the Wetherill collection of plant products from the Mancos cañon.

In $1892 \mathrm{Mr}$. Frederick V. Coville published valuable notes on the botany of the Panamint Indians of California, collected while he was a member of the Death Valley Exploring Expedition of $189{ }^{2}{ }^{2}$

Two very valuable articles have quite recently appeared, by Dr. V. Havard, U. S. A.: "The Food Plants of the North American Indians," 3 and "Drink Plants of the North American Indians."

In 1895 an article, "The Beginnings of Agriculture," by Mr. W J McGee, being a study of the Papago country, suggesting the influences exerted upon life in a desert environment, appeared in the American Anthropologist.

Still more recently Mr. J. W. Fewkes published a preliminary study of the "Foods and Food Resources of the Hopi Indians," 5 having then in preparation a more systematic memoir upon Tusayan botany. A supplementary article, "The Hopi in Relation to their Plant Environment," by Mr. Walter Hough, was printed in February, $1897 .^{\circ}$

As a guide to researches of this character the National Museum has recently issued a bulletin by Mr. Coville, Directions for Collecting Specimens and Information Illustrating the Aboriginal Uses of Plants.

These few notices will show the attention that the subject is likely to command in the near future.

Much valuable work was, however, done many years ago, particularly by Mr. Edward Palmer, ${ }^{7}$ and by Mr. Stephen Powers, ${ }^{8}$ which should have aroused a more general interest in this important subject.

2. The present study is an attempt to describe some of the native plant $r \in$ urces known and used by the Coahuilla Indians of southern Californiz The articles already published show how such a work may be conducted. There are few plants in an Indian country that have not been experimented with by its native inhabitants. A thorough study

I Botanical Gazette, Vol. XXI, No. 3. $\quad 2$ American Anthropologist, Vol. V, p. 35 I.

3 Bulletin Torrey Botanical Ciub, Vol. XXII, No. 3, March, 1895.

4 Ibid., Vol. XXIII, No. 2, February, 1896.

5 American Anthropologist, Vol. IX, No. I, January, 1896.

6 American Anthropologist, Vol. XX, No. 2, February, 1897.

8 "Aboriginal Botany," Proceedings California Academical Society, Vol. V. 
of the ethno-botany of any such region should properly include, of course, all plants used for foods or medicines, or which have been found useful in the arts, but also all such as have a religious significance, or that figure in the folklore of the Indians, or even such as are admired or worn for ornament, or that supply food for animals. What we wish to know is, how has the Indian satisfied all his needs out of the flora of his home. Ethno-botany properly touches every side of his life. We might go even farther than this and say that even those plants which he knows to be poisonous, or noxious, or mere nuisances, or which have proved absolutely useless to the Indian, so far as he recognizes these plants in his language, that is, has named them and understands them, are worthy of our notice. Such plants often show how diligent and acute, even though unrewarded, the investigation for useful things has been.

The present paper is an attempt to study, from this point of view, the native culture of one of the Indian tribes inhabiting the arid plains and mountains of the California desert.

The question that instantly arises in the mind of the visitor to the habitat of the Coahuillas is, how can any people find here the satisfaction of their wants. This question has guided these investigations, and the answer is attempted in this monograph and has determined its limits. At the same time, I have included considerable matter relating to the tribal relations of these Indians and their past history, for the reason that the Coahuillas are almost unknown outside of their own portion of the state, and the information heretofore published concerning them has been somewhat confused and mistaken.

3. The orthography used in writing Indian words is, in general, that used by the collectors of the Bureau of Ethnology. Vowels have the Italian values, etc. I have not followed, however, the plan of using $c$ for the sound $s h$, as I consider this spelling too misleading to those unacquainted with the system.

A word should be said also as to the pronunciation and spelling of the tribal name, Coahuilla. The word is Indian, and the tribesmen's own designation for themselves, and means "master" or "ruling people." There is some slight variation in its pronunciation, but the most usual is, probably, Kow-wee-yah, accent on the second syllable. The spelling has been various. The spelling adopted by the early writers, and correct, according to the value accorded to 11 in SpanishAmerica, is that adopted here, Coa-hui-lla. I have preferred this, although advised by Mr. C. F. Lummis to spell the name "Coahuia," the spelling demanded by the precise Castillian rule. 


\section{CHAPTER I.}

LINGUISTIC AND TRIBAL AFFINITIES OF THE COAHUILIA INDIANs.

4. A systematic account of the Indians of southern California has never yet been published. The work of Mr. Steponen Powers, The Indians of California, ${ }^{\mathrm{I}}$ considered no tribes south of -the. Saita, Inez. mountains on the coast, or the San Joaquin valley in the ntorior. The Indian tribes of California, south of these limits, fali into itree divisions: those of the Santa Barbara channel and islands, covering the whole coast of Ventura county; and two more groups occupying the lower portions of the state.

Any study of the first group must now be confined to the written accounts concerning them and to the numerous archæological remains, since these Indians are either wholly extinct or mingled with the present mestizo population. Of the latter two groups, however, several thousand ${ }^{2}$ are still living in some thirty different villages or small reservations in San Bernadino, Riverside, and San Diego counties, and are open to ethnographic investigations.

5. The habitable portion of southern California is divided geographically by low mountain ranges into a number of spacious valleys. In these fertile tracts, at that time well populated by Indians, the Franciscan friars, under the direction of the Spanish government, a century ago established their missions. Furthermost south, and the first to be established, was the mission of San D)iego ( I 769). It formed a center for reaching the numerous bands of Indians about the bay and scattered southward into Lower California, eastward to the desert, and for thirty or forty miles northward on the hills and niesas of the Coast Range. Forty miles north of San Diego, at the foot of the beautiful valley of the San Luis Rey river, was established, in 1798 , the mission of San Luis Rey de Francia. Twenty-five miles up the stream, near its headwaters, was the substation of Pala, in a narrow, hillsurrounded valley. This branch was to reach better the Indians living back from the coast in the fastnesses of inner cañons and valleys.

Near the coast, twenty-five miles north of San Luis Rey, was San Juan Capistrano, commanding the populous valley of the Santa Ana.

I "Contributions to North American Ethnology," Vol. III, Washington, 1877.

2 According to a recent government report, 3,48r. (Report of the Commissioner of Indian Affairs, for 1894.) 
Established in 1776 , it became one of the wealthiest and most prosperous of the missions. Twelve miles east of the present site of Los Angeles was San Gabriel (177I), and thirty miles northward at the upper end of the wide plain was San Fernando Rey de España (I 797).

6. The Indians attached to the mission of San Diego, whose name for themselves seems to have been Quemaya (Comeya, Comoyei), are a branch of the great Yuma linguistic family of the Colorado and Gila rivers, which thus extends from the Colorado across the desert to the Bacific sceati: "From their attachment to the mission, those about San Diego bay. and along the coast have become known as Diegeños, even "ationg themselves." Within the domain of the United States they still number about six hundred souls and have several small reservations in San Diego county, San Pasqual, Santa Ysabel, Mesa Grande, and others, while many more of the same family are scattered through the rough country of Baja California, just below the line, a well-known reservation being in the Jacumba pass, near the road from San Diego to Yuma. The Indians about San Luis Rey mission and up the river into the mountains are known as the "Luiseños." They number at present about $85^{\circ}$, and their villages are principally in the Pala valley, Pauma, La Jolla, and Rincon. With these should also be included the Temeculas at Pechanga, eight miles north of Pala.

The Indians, once neophytes at San Juan Capistrano, San Gabriel, and San Fernando, are gone. A few grizzled descendants may be still lingering in the shadow of the crumbling walls of the mission ruins, but the former tribes have disappeared; their survivors have either mixed with the mestizo population or joined the Indians further removed from civilization.

The two Indian tribes still to be mentioned are the Serranos and Coahuillas. The former live at a small reservation near San Bernadino ("Manuel's village") and on the Morongo reservation in the San Gorgonio Pass, where they have intermarried with the Coahuillas. The Coahuillas, the only tribe still designated by its Indian name, live in the Colorado desert and the San Jacinto range of mountains.

As was said above, there is no general account of these Indians that offers a suitable basis for further research, either into the history of those that have disappeared or the ethnography of those that are still in existence.

About twenty pages of Mr. Bancroft's first volume are devoted to the "Southern Californians." $\quad$ The account is of value for its references,

Native Races, Vol.I, pp. 402-22. 
indicating the written material that exists for this study. What is perhaps most needed at present is a bibliographical and critical study of these sources, historical, linguistic, ethnographic, and archæological, as a basis for the early and aboriginal history of southern California. It seems to be considerable in amount, but no sifted or critical presentation has yet appeared. This fact is my excuse for the considerable digression that follows, dealing with the linguistic relations of these Indian tribes.

7. For establishing the relations of the southern California Indians with one another and with other linguistic stocks of North America, the linguistic material seems fairly sufficient.

Scientific classification of the Indians of North America on the basis of language began with Albert Gallatin's "Synopsis of the Indian Tribes," which appeared in ${ }^{8} 8_{36}$. $^{*}$ His material for tribes west of the Rocky Mountains was small in amount, and the Indians of California are not included in his classification.

'The first linguistic material from Indians of California to be placed within the reach of scientists, of which I am aware, were vocabularies from several different Indian tongues collected by an Englishman, Dr. Coulter, during a residence of several years in southern California, and which were published in $184 \mathrm{I}$, by Dr. John Scouler, in the Royal Geographical Journal for that year, in an article entitled "Observations on the Indigenous 'Tribes of the North West Coast of America." z

These vocabularies include the languages spoken at the Franciscan missions of San Diego, San Juan Capistrano, San Gabriel, Santa Barbara, San Luis Obispo, and San Antonio. They contain something less than fifty words each.

In ${ } S_{4} \circ$ the French government, during the excitement incident to the disputed possession of Oregon, sent to the Pacific coast an expedition under Duflot de Mofras, who sailed the entire length of the California coast, visiting at many places, and who collected from the Franciscan friars their translations at the various missions, of the Paternoster into the Indian tongues. These are twenty-one in number and are to be found in De Mofras' account of his travels. ${ }^{3}$ They have also been reprinted in Bancroft's volume on the Native Races of California. 'This voyage of De Mofras' is of interest as the last expeditionary undertaking ever sent by the French into North America.

\footnotetext{
I Transactions of the American Antiquarian Society (Archaologica Americana), Vol. II, Cambridge, 1836 .

2 Royal Geographical Journal, Vol. XI, pp. 215-49, 1841.

3 Expédition de l'Oregon, etc.
} 
My own examination of this collection has been pretty fruitless of any results, but Mr. Gatchet professes to have found them useful in determining the distribution of Indian languages at the beginning of this century. These prayers may also be found printed in the sixth volume of the Proceedings of the Philological Society of London, ${ }^{2}$ where they are discussed in an inconclusive manner.

Mr. Horatio Hale, while a member of the United States Exploring Expedition, under command of Captain Charles Wilkes, in the years 18.38-42, collected several vocabularies from Indians at the California missions, among them the "Netela," spoken at Mission San Juan Capistrano, and "Kizh," spoken at Mission San Gabriel. These vocabularies contain approximately ninety words each and constitute very important records. Mr. Hale's commentary upon them is significant, although he hesitated to take decidedly the position, assumed some years later by Professors Turner and Buschmann, of classifying the Indians speaking these languages with the Indians of the great Rocky Mountain basin. Mr. Hale's words are as follows :

The similarity which exists between many words in these two languages and in the Shoshone is evident enough from a comparison of the vocabularies. The resemblance is too great to be attributed to mere casual intercourse: but it is doubtful whether the evidence it affords will justify us in classing them together as branches of the same family. The fact that the Comanches of Texas speak a language closely allied to, if not identical with, that of the Shoshones, is supported by testimony from so many sources that it can hardly be doubted. ${ }^{2}$

In 1846 there was published a very interesting little book by an American, to which all those interested in the early life of Spanish California, as well as in the Indian inhabitants, can well be referred. This book is entitled : Life in California: During a Residence of Several Years in that Territory, etc. By an American. To which is annexed a Historical Account of the Origin, Customs, and Traditions of the Indians of Alta California. Translated from the original Spanish Manuscript. ${ }^{3}$ The author of this volume was a Mr. Alfred Robinson. His account of his own travels in California is interesting reading, but possibly no more valuable than that of several other early visitors to the state,

I LAtнaм, "On the Languages of New California," Proceedings, 1852-53, Vol. VI.

2 Horatio Hale, " United States Exploring Expedition," Ethnology and Philology, pp. 566, 567. Philadelphia, $\mathbf{8 8 4 6 .}$

3 The publishers of the first edition were Wiley \& Putnam, New York, 1846. The edition is scarce, and a copy sells from $\$ 8$ to $\$$ ro. The Life in California has been reprinted by Mr. William R. Doxey, San Francisco, but without the Account . . . of the Indians by Father Boscana. The Chinigchinich is reprinted entire in the California Farmer, Vol. XIII. 
whose books are more accessible. The account of the Indians is the unique and valuable work, and the Life in California was really written to serve as an introduction to this translation. This part bears the following separate title: Chinigchinich: a Historical Account of the Origin, Customs, and Traditions at the Missioniry Establishment of St. Juan Capistrano, Alta Californial called the Acagchemem Nation, collected with the greatest care from the most intelligent and best instructed in the matter. By the Reverend Father Friar Geronimo Boscana, of the order of Saint Francisco, Apostolic Missionary of said Mission. Translated from the original Spanish manusiript by onc who wens many years a resident of Alta Califormia. In his introduction Mr. Robinson says:

The manuscript ends rather abruptly; and it is uncertain if the boly father ever intended it for publication. After his death, in $8_{3} 1$, it was found among his effects, with other writings which came into the possession of the syndic of the missions, who kindly presented it to me.

Father Boscana's account is cast in the naive and pious language of a Franciscan missionary, but he certainly gives us a very reliable account of the Indians of the section in which his labors were cast, and the dances, feasts, and customs as he describes them have been astonishingly well preserved to the present day. His display of Indian words is, however, meager. The words he gives us, for the most part, relate to the ceremonies and social order of these Indians, so that they are not especially helpful for our immediate purpose. The great value of Chinigchinich is ethnographical and not philological."

In I 852 a series of valuable papers on the "Indians of Los Ingeles County" were published in the Los Angeles Star, by 1)r. Hugo Reid, a liberally educated gentleman of scottish birth, who resided at San Gabriel for twenty years previous to his death in 3853 , and whose observations, recorded in the above papers, constitute undoubtedly one of the most authentic accounts of the Indians of southern California. Bartlett, in his Personal Varrative, writing of his visit to Los Angeles in 1853 , says :

After dinner I called at the office of the Los Angeles Star to obtain a file of the paper, which contains a series of articles on the California Indians. ... These gentlemen informed me that Mr. Reid was better acquainted with the Indians of that portion of the state than any other person. ${ }^{2}$

I The words in Boscana's narrative were most patiently examined by Buschmann.

2Personal Narrative of Explorations and Incidents in Texas, New Mexico, California, Sonora, and Chituahua, connected with the United States and Mexican Boundary Commission, during the years $1850,51,52$, and 53 , by JoHN RUSSELL BARTLETT, United States Commissioner during that period; two volumes, illustrated, and maps. N. Y.: D. Appleton \& Co., 1854 . 
Already, in I861, Mr. Alexander Taylor wrote of these letters of Mr. Reid that they formed the "only account of the Indians of that country of any value," "now out of print," and that " this history of Mr. Reid's is accounted of great value among the ethnologists of Europe and America, who have repeatedly sent to this country for it without avail, as no complete copies of it are now to be had in the state." In these letters is contained a vocabulary of the Indians about San Gabriel, containing, including twenty-four numerals, about fifty words. Other words and expressions scattered through these letters bring up the linguistic material afforded by this writer to about seventy words.

In 1857 , Lieutenant Whipple, in charge of the surveying party for a United States Pacific railroad, collected some Indian vocabularies, which had much to do with settling the linguistic affiliations of the Indians of southern California, and which are still among the best collections ever published from these localities. While still in Arizona, at the junction of Bill Williams fork with the Colorado river, Lieutenant Whipple's party encountered the Chemehuevi Indians, whose place in the treatment of the Coahuilla nation will be noted later. These Indians Whipple considered "a band of the great Pai Ute nation. . . . At night the chief furnished us with a vocabulary of his language. He drew also a sketch of this country, giving the Pai Ute names of tribes and the rivers where they dwell." ${ }_{2}$ This vocabulary contains about 175 words, and is presumably the first ever published of the Chemehuevi Indians. After crossing the Mojave desert and entering the inhabited part of southern California, Mr. Whipple's party stopped for a day at the Cucomonga ranch, about forty-five miles east of Los Angeles. Here there was a rancheria of Coahuilla Indians, apparently peons of the ranch. "With them," says the narrative, "is an old Indian, dressed in an entirely new suit, in the style of a California ranchero, and he professes to have come from Jose Antonio, the general-in-chief of the tribe..... As he spoke Spanish we were enabled to obtain a vocabulary of his native tongue." This vocabulary of the Coahuilla language, comprising about 150 words, is much the best that has ever been published. The words and the pronunciations, so far as I can judge, are in almost every case identical with the speech of the Coahuillas at the present time. The words for parts of the body in Mr. Whipple's collection have all the first-person possessive pronoun, nè , affixed, a thing that almost invariably happens in getting

California Farmer, Vol. XIV, p. 146.

2 Lieutenant A. W. Whipple, Report of Explorations for a Railway Route near to the Thirty-fifth parallel of North Latitude from the Missouri River to the Pacific Ocean. Washington, x853-54. Part I, "Itinerary," p. III. 
these words from an Indian, but this error is easily rectified. Mr. Whipple's linguistic material collected on this expedition was analyzed by Professor William W. Turner and printed in the Expedition's report upon the Indian tribes. ${ }^{x}$ In this report the Comanche, Chemehuevi, and "Cahuillo" vocabularies are printed in comparative columns under the title "Shoshonee." A comparative vocabulary was also published, embracing twenty-eight "Cahuillo" words, together with an equal number from Mr. Hale's "Kizh" and "Netela," and from a manuscript vocabulary of the Indians at San Luis Rey mission, procured by Hon. John R. Bartlett, while engaged upon the Mexican Boundary Survey, and called by him the "Kechi."” Professor 'Turner's conclusion in regard to the Comanche, Chemehuevi, and Cahuillo, was that

the natives who speak these languages belong to the great Shoshone or Snake family: which comprehends the Shoshones proper of southern Oregon, the Utahs in the region around the Great Salt Lake and then extending south and west the Pah-Utahs, west of the Colorado and the Indians of the missions of southern California, the Kizh (of San Gabriel), the Netela (of San Juan Capistrano), and the Kechi (of San Luis Rey), and on the south and east the Comanches of the prairies. ${ }^{3}$

To these collections of Lieutenant Whipple and the analysis of I'rofessor Turner is due also the establishment of the Yuma linguistic family, including the Mojaves, Cuchans, Maricopas, and I Iegreño Indians, and the connection of the Diegeno Indians therewith. ${ }^{4} \mathrm{~A}$ vocabulary of the Diegeños, furnished by Dr. Coulter, had already been, as we have seen, ${ }^{5}$ published in the eleventh volume of the Koyal Geographical Society's Journal, and the paper of Mr. Latham "On the Languages of New California" ${ }^{6}$ attempted to classify the Indians of southern California on the basis of De Mofras' Paternosters; but that the Diegeños were close kin to the tribes of the Gila and Colorado rivers seems not to have been suspected previous to Mr. 'Turner's discovery of the relation.

From I 853 to 859 the linguistic connections of these Indians excited the interest of Dr. Johann Buschmann. 'This learned philologist, searching for traces of Aztec speech among the Indian languages of

I Ibid., chap. 5, "Vocabularies of North American Language," pp. 71-77.

${ }^{2}$ In his Personal Narratize, Vol. II, p. 92, MR. Bartletr speaks of his visit to the San Luis Rey mission and of "an old chief" who was quite communicative of information and furnished a "vocabulary. . . . . He called his tribe the Kechi." This vocabulary contains twenty-eight words.

3 Ibid., p. $7^{6}$.

4 The vocabularies for this analysis were collected by Lieutenant Emory in 1854, while engaged on the Mexican Boundary Survey, and are printed in the reports of that expedition.

5 Supra, p. Ir.

6 Supra, p. I2. 
northern Mexico, found such existing in four widely used Mexican tongues - the Cora, the Tepehuana, the Tarahumari, and the Cahita. These comprise what Buschmann calls his "Sonoran linguistc family" (sonorische Sprachstämme). The connection of these languages in the past with the Aztec is now, I believe, generally accepted. Continuing his investigations into the languages of the southwest United States, Buschmann discovered similar traces, arguing for an earlier common speech from which all could be descended, in all members of the Shoshone linguistic family. ${ }^{x}$ The results of these labors are stated by Dr. Brinton as follows :

The relationship of these numerous bands is unquestionable, although many of them have freely adopted words from other stocks. The principal members of this stock are the Utes, Shoshones, and Comanches in the north; various tribes in Sonora, Chihuahua, Sinaloa, and Durango in the center; and the Nahuas, or Aztecs, in the south. It is not to be understood that any one of these derived its idioms from the other, but rather that at some remote epoch all three were offshoots from one ancestral stem. ${ }^{2}$

Buschmann's first essay on the languages of southern California was a study of the two vocabularies furnished by Horatio Hale, the Kizh (of San Gabriel), and the Netela (of San Juan Capistrano), and was published in the Proceedings of the Royal Academy of Sciences of Berlin for the year $1855^{3}$ In these two vocabularies from the Pacific coast Buschmann recognized evidences of the widespread aztekischen Sprache, which he was so zealously tracing from the Mexican highland northward through Mexico to the great American desert of the southwestern United States.

Bei der genugsam von mir aufgezeigten Gemeinschaft der zwei californischen Idiome, so lautet mein Urtheil, hofft man auch hier vergebens auf ein genaues, glückliches Zutreffen eigenthümlichen Formen dieser Sprachen mit dem Comanche und Shoshonischen oder mit dem südlichenen sonorische Hauptsprachen, ein Zusammentreffen mit etwas recht Besonderen einer Sprache mit einer anderen; so nahe liegen die Sprachen sich nie, die sind alle fremd genug gegen einander. ${ }^{4}$

Buschmann's final work is the remarkable essay published four years after the above in the Royal Academy's Proceedings: "Traces of

I Major Powell does not seem to consider this evidence sufficient to support either Buschmann's or Brinton's conclusions as to an earlier common stock.

2 The American Race, p. 118 . New York, $189 \mathrm{r}$.

3 Die Sprachen Kizh und Netela von Neu California. Abhandlungen der Königlichen Aka. demie der Wissenschaften $z u$ Berlin, 1855.

4 Ibid., p. 318. 
Aztec Speech in Northern Mexico and Upper North America, etc." The work shows immense labor and brilliant powers of analysis, and is a model and standard for all such undertakings. The first part deals with the Mexican linguistic stocks (der vier sonorischen Hauptsprachen) above noted. The second part traces the common tongue northward into Arizona, with examinations of the Pimas and Coco Maricopas of the Gila, the Yumas of the Colorado; the Moqui, Navajos, and Apaches; and eastward the language of the Comanches of Texas. This brings him to a consideration of the Indian tongues of southern California. For determining the relationship of these tribes Buschmann had no sources of information beyond those we have already noticed. Beside the vocabularies of Horatio Hale, Buschmann used Dr. Coulter's work, published by Scouler, a vocabulary of the 1)iegeños collected by Lieutenant Whipple, ${ }^{2}$ the words derived from Father Boscana's account of the Indians of San Juan Capistrano, Bartlett's vocabulary collected at San Luis Rey, the "Kechi," De Mofras' "Paternosters," and, most important of all, the critical studies of Professor Turner based on the vocabularies published in the Pacific Railway reports; Buschmann's discoveries from this last source are worth quoting in his own language:

Als ich das Obige vor einigen Jahren schrieb, habe ich nicht geahnet, dass ich in der Kechi-Sprache ein Glied des sonorischen Sprachstammes erkennen sollte: es war an dem von Duflot mitgetheilten Sprachstoffe auch nicht zu sehn. Als ich in Juni des Jahres 1857 durch die Güte des Hon. Professor Turner die, von ihm redigirten Wortverzeichnisse der Whippleschen Expedition der Jahre I 853-5+ (Report, etc.) erhielt, endeckte ich darin zwei neue sonorischen Sprachen angehörig dem südlichen Neu-Californien: die der Chemehuevis (Humboldt's Chemeguabas am unteren Colorado), der Cahuillos (zwischen den Quellen des S. Ana und S. Gabriel), und das Kechi, oder die Sprache der Mission San Luis Rey. Von den beiden ersten hat Whipple ein grosses Wortverzeichniss gesammelt, das Turner mit einen Comanche-Wort, (PP. 7I-6) zu einer Worttafel zusammengestellt hat, die sein allgemeine Shoshonee-Idiom vorstellen soll. Um die bedeutende Verwandschaft des Cahuillo mit dem Kechi, Netela, und auch Kizh zu zeigen, hat er (p. 77) eine Tafel, etc. ${ }^{3}$

He repeats here his former conclusions about the Kizh and Netela :

I Die Spuren deraztekischen Sprache im nördlichen Mexico und höheren anerikanischen Norden. Zugleich eine. Wusterung der Vïlker und Sprachen des nördlichen Wexicas und der Westseite Nordamerikas von Guadalaxara au bis zum Eismeer, von JoH. CARL ED. Buschmann. Berlin, 1859 .

2 Published in Schoolcraft, Vol. II, pp. 103, 104.

3 Spuren, etc., p. 550 . 
Zwei Sprachen im südlichen Neu-Californien, gelegen nördlich über San Diego, am Canal de S. Barbara, habe ich von hoher Wichtigkeit gefunden : ich habe in dem Kizh oder der Sprache der Mission San Gabriel, in etwa $34^{\circ}$ N. B., und in der Netela oder Mission San Juan Capistrano, in $331 / 2^{\circ}$, zwei Glieder meines sonorischen Sprachstammes ausgestaltet mit aztekischen Sprachstoff, endeckt. ${ }^{x}$

Foremost among the enthusiastic workers in California ethnology was Mr. Alexander O. Taylor. In February, I 860, Mr. Taylor began to edit, in a weekly paper published in San Francisco, The California Farmer and Journal of Useful Sciences, of which Colonel Warren was the editor and publisher, a department entitled the "Indianology of California," and for over three years in these columns, with nearly every number of the paper, was published a large amount of very valuable material on the California Indians and early California history, the result of Mr. Taylor's persistent gleanings and his own excellent observations. In this series were published the very valuable works noted above, Mr. Hugo Reid's "Indians of Los Angeles County" and Robinson's "Boscana's Chinigchinich." Mr. Taylor published here a number of excellent vocabularies, gathered by himself at the different missions, two of which we must notice. No. 9 is a vocabulary of about 130 words, besides a few numerals and phrases taken from an old Christian Indian about sixty years old at the mission San Gabriel.2 No. Io was taken at San Luis Rey mission in April, $185_{6}^{6}$, but it is not the vocabulary of a Luiseño Indian at all but of some visiting Diegeño Indian from farther south. Following it is one secured from an Indian from San Miguel mission of Lower California. The frequent references in this essay to these publications of $\mathrm{Mr}$. Taylor will suggest to what an extent we are indebted to him as a gatherer and preserver of what would otherwise have been well-nigh inaccessible material.

In 1875 there were collected by Dr. Oscar Loew vocabularies from various Shoshonian tribes; from the Pah-Uta and Chemehuevi in Nevada and California, and from the few surviving Indians at San Gabriel and San Juan Capistrano, as well as from the Coahuilla and Serrano Indians near San Bernadino. In 1878 Dr. Eric Bergland secured a vocabulary from the Luiseño Indians about San Luis Rey. This new material, together with much more from the southwest tribes, was studied by Mr. Albert S. Gatchet and printed in an appendix to Vol. VII of Archaology, of the Reports of the U. S. Geological Survey (Washington, 1879), "Classification of Western Indian Dialects."

\footnotetext{
I Spuren, etc., p. 546.

2 California Farmer, Vol. XIII, p. go.
} 
Mr. Gatchet's classification includes seven linguistic stocks. For the one with which we are here concerned, the Shoshone, he substitutes a new term "Numa," a word which he states is found in most of his Shoshone vocabularies meaning "man," "Indian," or "people."

"The Numa race of aborigines," he says, "is an inland race extending over a large portion of the great interior basin from middle Idaho southward to the Colorado, the Colorado Chiquito and the Rio San Juan; one of its subdivisions, the Comanche tribe, has overrun the vast plains extending between the Arkansas and the Rio Grande, while another branch has in early days occupied portions in eastern and southern California. This is the only Numa offshoot which, as far as we know, has settled on the shore of the Pacific ocean." I

This "Numa race" is composed, according to Mr. Gatchet, of eight linguistic families--the Shoshone, Snake, Pa-Uta (in which family are placed the Chemehuevi), Pa-Uta of California, Uta, Moqui, Kauvuyah, and Comanche. "Kauvuyah" is the designation he adopts for our group of California Indians. Mr. Gatchet says that it is "the orthography adopted by Oscar Loew for the name of one of the Serrano or mountain tribes," and again, "Kauvuyah, on the oases in Cahuilla valley, at the San Gorgonia pass, at Temecula, and in the San Jacinto mountains, written also Cahuillo and (incorrectly) Coahuila." It thus seems that Kauvuyah is the way in which Mr. Loew conceived that Coahuilla should be written. As commonly pronounced the word might be written Kau-wee-yah. Invariably, however, in all the Coahuilla words which Mr. Loew collected, $v$ and $w$ are interchanged, an error due possibly to his nationality. Kauvuyah is thus probably meant to be pronounced Kauwüyah. This is not very far off from the correct pronunciation, but it is certainly an unrecognizable spelling, and it has unfortunately been followed both in the works of Major Powell and Dr. Brinton. Mr. Loew also invented new tribal designations for the dialects he collected at San Juan Capistrano and San Gabriel. The former he called "Gaitchim," the word in his vocabulary for "houses," and the latter "Tobikhar," and the Serranos he renamed "Takhtam," the word in his vocabulary of their language meaning "men."

The Serrano word for men is more nearly "takhtem" than "tahktam." The Serranos' own designation for themselves is Ców-ang-a-chem. It is difficult to understand what value these names can have as

IOp. cit., p 408 .

2 In recounting the creation myth of the San Gabriel Indians Mr. Hugo Reid states that the first man was named "To-bo-har." The word for man in his vocabulary is "woroyt." (See "Indians of Los Angeles County," California Farmer, Vol. XIV, p. 146.) 
tribal designations, or why the Kizh and Netela of Mr. Hale should be removed to make way for them. Gaitchim, Tobikhar, and Takhtam are pure inventions, unheard of as tribal designations by anyone in southern California, yet all these terms have been adopted by $\mathrm{Mr}$. Gatchet, Major Powell, and Dr. Brinton and can serve only to confuse anyone who tries to study and collect vocabularies of these Indians on the ground. Mr. Loew's vocabularies contain about I 50 words each, taken according to Mr. Gibb's Indian vocabulary. Besides confusing the $v$ and $w$, in the Coahuilla vocabulary at least, $b$ often takes the place of $p, g$ of $k$, and vice versa ; in many words the personal pronoun $\breve{n e}$ is affixed in its several modifications. These defects prevent the vocabularies from being trustworthy.

In an article, "Indian Languages of the Pacific States and Territories," “ Mr. Gatchet had the following paragraph :

Kauvuya (Cawio; Spanish, Cahuillo). This branch of the Shoshoni stock prevails from the Cabeson mountains and the San Bernadino valley, California, down to the Pacific coast, and is at present known to us in four dialects: Serrano, or mountain dialect, spoken by Indians who call themselves Takhtam, which means "men," "people ;" Kauvuya, in and around San Bernadino valley, Gaitchim or Kechi, a coast dialect, in use near the missions of San Juan Capistrano, and San Luis Rey de Francia - Netela is another name for it; Kizh, spoken in the vicinity of the mission of San Gabriel by a tribe calling itself Tobikhar, or "settlers," and of San Fernando mission, almost extinct. The two last-mentioned dialects considerably differ among themselves and from the mountain dialects of the Takhtam and Kauvuya.

Mr. Gatchet is in error when he speaks of the Serrano and San Gabriel Indians "calling themselves" Takhtam and Tobikhar, respectively. The words are unknown as tribal designations among these Indians themselves, and precisely this point constitutes the objection to them.

The interest in Indian languages awakened by Major Powell's study and the collections made for his report by the Bureau of Ethnology do not appear to have added anything to our knowledge of these Indian languages. No mention of vocabularies appears in the account of the results of this work. ${ }^{2}$

Major Powell speaks in his Linguistic Families only of the "Tobikhar, about twenty-two hundred under the Mission Agency, California," 3 seeming thus to include the entire Coahuilla family under this designation.

I Magazine of American History, March, 1877 .

2 J. C. Pilling, Catalogue of Linguistic Manuscripts in the Library of the Bureau of Ethnology, First Annual Report of Bureau of Ethnology, 1879-80, pp. $545 \mathrm{ff}$.

3 Indian Linguistic Families of America, north of Mexico, in Seventh Annual Report of the Bureau of Ethnology (Washington, I89x), p. 1 ro. 
Dr. Brinton enumerates under the Shoshonean branch of his UtoAztecan linguistic stock the "Cahuillos in southern California," "Chemehuevis, branch of the Pi-Utes on Cottonwood island ;" "Kauvuyas, southern California, near the Pacific;" "Kechis, in southern California, branch of Kauvuyas;" "Kizh, in southern California, branch of Kauvuyas ;" "Netelas, in southern California."

8. The above material is sufficient to enable us by its analysis to form a number of conclusions.

From the outset philologists have been almost unanimous in separating these Indians from the California tribes to the north and connecting them with the great Shoshonean family of the deserts to the east. As the early migrations of these tribes spread they not only overran the whole of the vast arid expanse east of the Sierras, but in the south they crossed by the passes that pierced these mountain ranges from the desert into the fertile valleys and coast lands of southern Calfornia. From the Mojave, they appear to have entered the southern end of the San Joaquin valley and to have secured a foothold there, leaving their name to the locality there, spelled in anglicized form 'Kaweah, as Coahuilla is the Spanish orthography. Bancroft ${ }^{2}$, quotes from a manuscript furnished by Mr. Hayes that the "Tulareños (of the San Joaquin valley) live in the mountain wilderness of the Four Creeks, Porsiuncula or Kern or Current river, and the Tejon; and wander thence toward the headwaters of the Mojave and the neighborhood of the Coahuillas." A vocabulary of the "Four Creek Indians" was published under the name of "Ka-we-yah" in the Wide West Magazine, July, i 856 , San Francisco, and is reprinted entire in the California Farmer, Vol. XIII, p. Io6. In this vocabulary, which consists of about 125 words and phrases, there are few traces of Shoshonean speech. The Coahuillan tribes entering the San Joaquin must have lost their own speech in favor of that of the previous inhabitants, while retaining their original tribal name. One or two words are, however, suggestive of Coahuillan origin. The phrase "hang-ah ka-woowah" is said to mean "powerful man," the word "kawoowah" signifying "power, strength, ability," just as farther south the word "kawoowah" or "kaweah" or "coahuilla" means "master" or "ruling one." The word "mee-wah" is given as meaning "friendly," an expression still used among the desert Coahuillas far to the south with apparently much the same significance as a hail on approaching a strange campfire. These linguistic evidences, though slight, support the evidence ID. G. BRInton, The American Race (New York, r89r), p. 133.

2 Native Races, Vol. I, p. 457. 
of this being an early Coahuillan migration from the Mojave into the San Joaquin valley.

Southward from the Mojave they passed through the Cajon pass into the region around San Bernadino, and thence spread to the coast through the valleys of the San Luis Rey, Santa Ana, and San Gabriel rivers. Those who settled farther north about San Fernando may have gone there from the San Gabriel valley or entered this region directly from the Mojave, by way of Antelope valley.

Mr. Alexander Taylor, writing in 1862 , says of the Saticoy valley, west of San Fernando:

This valley at the upper end communicates with the Tejon and Los Angeles roads, and for the last forty years has been a gate for the entrance of Utahs, Paiutes, Yutes, Mojaves, and other desert and mountain Indians who possess horses. Their visits were always made to run off the mules and horses of the Padres and latterly the rancheros up to 1850 . In this way probably the Shoshone affiles entered these parts of California. ${ }^{\mathrm{x}}$

An examination and comparison of all the vocabularies above noted proves without question the linguistic affinity of the tribes who formerly occupied southern California from San Fernando and contiguous territory south to the country of the Diegeños or the Quemaya, below Palomar mountain, and the San Luis Rey valley. It is impossible, within the limits of this paper, to print the evidences of this relationship. It must suffice to say that I have examined carefully all of these vocabularies mentioned, and find that of the languages spoken at San Fernando, San Gabriel, and about Los Angeles, San Juan Capistrano, and San Luis Rey, all possess a general similarity to the present speech of the Luiseños and of the Coahuillas. Many words are identical, or very nearly so, in all; and a great many others show slight or recognizable variations. The similarity between the languages spoken at San Juan Capistrano and San Luis Rey and the languages of the Luiseños and Coahuillas is much greater than the resemblance that connects these with the tongues of San Gabriel and San Fernando. The Coahuillas hunted and settled almost up the San Gabriel river, and yet the linguistic differences, as well as the relations between themselves and the Gabrieleños are decided, but a sufficient similarity exists to connect them all in one family.

I suggest for the designation of this great group of Shoshonean Indians and tongues the term "Coahuillan linguistic family," following Major Powell's method of adding an or ian to the naine of the most California Farmer, Vol. XVI, No. 15. 
prominent tribe to form the title for the family. The Coahuillas were and are the most powerful and best known of all these tribes. They are the only one that preserved in common use their own designation of themselves, and they are the only people of this family, except the Luiseños, who have survived as a nation to the present time. For all these reasons I consider the designation a good one.

In announcing this widespread linguistic relationship I am simply reiterating, after the most general study possible, a fact previously understood and stated, as has already appeared.

Major McKinstry, writing in the San Francisco Herald under date of June, I 853 , spoke of the immense area of San Diego county as containing

about 3,000 Indians, divided into three distinct nations or tribes: Yumas, 500; Coahuillas, 2,000; Dieguinas, 500. The two last-named tribes are again subdivided into mission or Christianized Indians and gentiles. . . . The Dieguinas reside in the southern part of the county, and claim the land from a point on the Pacific to the eastem foot of the mountains impinging on the desert. The Coahuillas reside in the northern half of the county and southern part of Los Angeles; they claim a strip of country commencing on the coast and extending to within fifty miles of the Colorado river, following the eastern base of the mountains. The division of territory is well known to, and recognized by, the Indians.

About 500 of the Coahuilla nation originally belonged to the mission of San Luis Rey, and are now residing at Pala, Temecula, Ahuanga, Agua Caliente, San Jacinto, and some few at and about the missions. A portion of the Coahuillas never acknowledged allegiance to the missions, and, of course, were not subservient to the will of the friars. Yet no villages of theirs, not excepting those on the desert east of the mountains, fail to send forth representatives during the harvest in the southern counties of the state. ${ }^{x}$

9. It is important to understand the peculiar connection of the Coahuillas with the Pah Ute and Chemehuevi branches; because, this being true, we shall expect to find their mode of life, their foods, and their ethno-botany in general intluenced by these desert tribes, and we shall not be surprised to discover among the Coahuillas many ethnographic details that suggest the life of Indians living far to the east of them. It is important to notice that the Coahuillas have remained in close and constant connection with their Shoshone kinsmen. In spite of Buschmann's conclusion that the "Chemehuevi and the Cahuillo languages are so foreign to one another that they possess for nearly all ideas wholly different words," it is true that the relations of the Coahuillas with

I Quoted in the California Farmer, February I5, 1861. 
the Chemehuevi have always been and still are most intimate. There seems to be more friendly-feeling and more intimacy between these two tribes belonging to different linguistic families than between the Coahuillas and any of the other Indians of their own family, who speak an almost identical dialect, as the Luiseños, for example. The Chemehuevi, from their reservation on the Colorado river, are still frequent guests in the jacales of the Coahuillas, and come annually to the San Bernadino mountains, north of the Cabeson, to hunt. Coahuilla Indians have even told me that the two tribes formerly constituted one nation and that their languages are still but little different. This seems at variance with the linguistic evidence that has so far been presented. But the vocabularies that we have of the Chemehuevi are very scanty. A fuller study of these two languages may reveal a closer similarity than has before this been discovered, and that is, I believe, in accordance with the historical relations of these two tribes.

The reports of the Indian agents in southern California speak often of this connection. For instance, as late as 587 I Mr. Stevens reported that "the Coahuillas are far less civilized (than the mission Indians) and affiliate more with the wild Indians of the plains and the Colorado river." " A plan being proposed about this time to establish a common reservation for all the Indians of southern California, Don Juan Foster, of Los Angeles, stated that the Coahuillas would not affiliate with the other "mission tribes." 2 On the other hand, it was frequently proposed by government representatives among these. Indians that the Coahuillas be removed to the Colorado and established on a reservation with the Chemehuevi. During all these years the Chemehuevi were troublesome Indians. The reports frequently complain of their depredations. They seem to have been involved for years in difficulties with the Mojaves, and these latter, being much the stronger nation, would drive them from their villages on the Colorado. They would then cross the desert with numbers doubtless augmented by renegade Coahuillas and run off stock from the San Bernadino valley. Mr. J. Q. A. Stanley, special Indian agent, wrote from Los Angeles in I 866 :

The Chimchinvis on the Colorado river and the Pah Utes of the desert have been quite troublesome during the last year. Several persons have been killed by them and many animals stolen. These Indians are composed of roving bands, having no fixed habitation, but changing from one watering place in the desert to another, in order to pick up a precarious living. ${ }^{3}$

$x$ Report of the Indian Commissioner, $187 x$, p. $69 x$.

2 Ibid., p. 16r.

3 Rept. Ind. Com., 1866, p. 102. 
A year later Mr. Stanley, having made a visit to the desert villages of the Coahuillas, wrote:

At Agua Caliente (a Coahuilla rancheria in Palm Valley, east of San Bernadino) I found the principal chief of the Chemehuevis, a tribe that has been living on the west side of the Colorado river above La Paz. These Indians, having engaged in a war with the Mojaves, were beaten, and after the loss of many of their number were obliged to flee for protection to the Coahuillas of Cabeson valley, and were living on the mescal plant and such other food as they could pick up.

The route traveled between these two tribes is an almost direct trail running eastward from the Cabeson valley to the Colorado. In places this path has been worn deep in the ridges of rock over which it passes. The Indians take about two days to make the trip.

\section{CHAPTER II.}

THE HABITAT OF THE COAHUILLAS.

Io. 'The eastern half of southern California is everywhere a desert, separated from the coast by the lofty elevations of the Sierras and the Coast Range. Northward in Inyo county is the sterile and dangerous depression famous as Death Valley. Southward, stretching from the Colorado to the Sierras, is the Mojave, the most elevated and least barren of these plains. Although its appearance is desolate, owing to the volcanic character of its rocks and its drifting beds of sand, the southern portion, now traversed by the Santa Fe Railway route, bears a valuable growth of bushes, contains many water holes, and has always proved a safe and direct route of travel. It was crossed by the old Mormon road from Salt Lake City to San Bernadino, as well as the overland trail from Santa $\mathrm{Fe}$, both roads meeting near the western side of the desert on the Mojave river. The San Bernadino range and a low spur running southeastward to the Colorado river, where it is known as the Chocolate mountains, separate the Mojave from the Colorado desert. This great depressed area occupies almost the whole southern part of the state and the northeastern part of Lower California, clear to the Gulf. The northwestern portion, enclosed by the San Bernadino range and the San Jacinto mountains, is the Coahuilla or Cabeson valley, the present home of the desert Coahuilla Indians. This valley is reached from the coast by the San Gorgonio pass. From Colton eastward, there is a long and continuous ascent for thirty miles, 
or nearly to Banning, where the divide is reached. From this point there is a descent through the pass into the Cabeson valley. Immediately from here onward one recognizes that the country and life have changed. Dry, gravelly stretches take the place of the red, alluvial soil on the other side of the summit. Stunted creosote bushes dot the plain, but there is an absence of trees and less hardy kinds of vegetation. Where the pass widens out into the valley the road crosses the White Water river. This considerable and refreshing stream, flowing from the snow peak of Mount San Gorgonio on the north side of the pass, pours itself across the rocky cañon, and then turning east onto the sands disappears before it has gone a mile. The descent is still very rapid. Vast deposits of wind-drifted sand impede one's progress and desolate the upper end of the valley. Gradually, however, these disappear, and the soil becomes a fine dark silt, the alluvial floor of an ancient fresh-water lake of wide extent, over which are dotted "montes" or clumps of mesquite, amidst which the Coahuillas have for generations dug their wells and built their homes.

II. Underneath the soft deposits of soil that cover the Cabeson valley there is a constant seepage of the waters that, falling upon the desert faces of the mountains, sink into the hot sand of the desert as soon as they emerge from the cañons and gorges of the hills. The depth of this subsurface flow varies in different parts of the valley, being greatest at the upper end. Indian Wells, west of Indio, is twenty-five to thirty feet deep, but in the lower parts of the Cabeson, toward the Salton Sink, water is reached at from twelve to sixteen, feet below the level of the sand. In his most delightful work, the Discovery of America, Mr. John Fiske, in reviewing the culture of the southwest tribes of the United States, speaks of their irrigating as " mainly an affair of sluices, not of pump or well, which seem to have been alike beyond the ken of aboriginal Americans of whatever grade." I The statement is in part disproved by the Coahuillas. For generations they have been well-diggers. Their very occupation of this desert was dependent on their discovery of this art. The whole valley of the Cabeson is dotted with wells, most of them marking sites of homes long ago abandoned, the wells themselves being now only wide pits partly filled with sand, but many dug in the old way still remain, supporting life and giving refreshment miles and miles away from the rocky walls where the streams of the mountains disappear in the sands. These wells are usually great pits with terraced sides

I Fiske, The Discovery of America, Vol. I, p. 84. 
leading down to the narrow hole at the bottom where the water sparkles, built in such a way that a woman with an olla on her head can walk to the very water's edge and dip her painted vessel full. The deeper it is down to the water, the larger, of course, is the excavation and the greater the diameter across its upper terrace. 'The Coahuillas call these wells téma-ká-wo-mal-em, a pretty figure. Ká-wo-mal is the word for a tinaja or water olla, and temal is the word for the earth or the ground. There is no question but that the Coahuillas learned of themselves to dig these wells, and this practice cannot perhaps be paralleled elsewhere among American Indians.

The low San Bernadinos to the north of the Cabeson valley are called by the Coahuillas Ká-wish-Po-po-ki-ut, or the "mountains of mesquite and tules," a name which their desolate, sandy appearance belies. The splendid San Jacinto range on the south is called the Káwish-wa-wat-ácha, or the "lofty mountains." Across the San Bernadino hills is the way to the Chemehuevi country, and behind these peaks these Indians annually make their camps when they come to this region to hunt mountain sheep. Up the San Jacinto ridges, dark and gloomy with shadows, run the ancient trails by which the Coahuillas entered the mountains and became hillsmen, as well as men of the desert. These trails - or "pit-em," as the Indians call them are almost unmarked paths. They ordinarily climb out of the desert across some great alluvial fan of cañon detritus and then follow up some deep gorge until the roughness of its torrent-swept bottom compels one to pull his scrambling pony up onto the great black ridges, that look like the giant vertabræ of fossil monsters. Water is terribly scarce in these mountains, and most of these trails converge at a little valley north of a peak of the range, Torres mountain. This valley is known to hunters as "Piñon Flats," from its forest of juniper, and here water can always be found. Long ago there was a small village here, and the site is still known to the Indians by its old name, Kwále-ki. High up on the northern side of 'Torres was another called Pa-nach-sa. These villages seem to have been halfway camps between the desert and the mountain rancherias farther on, and probably never more than a few families occupied them at a time. The elevation is five or six thousand feet higher than the desert, and the air bracing and fine. And from these eyries one can gain a wide view of the Coahuillas' home.

These mountains, arid as they are, and scantily supplied with vegetation as they seem to be, are nevertheless rich in botanical species, and 
the region is one of wondrous interest to the collector and of great value to the Indian, for it is from here that there come many of his most valued plant products.

I2. The peculiarities of desert life have been often remarked. The physical and social effects upon the plant and animal species inhabiting the desert have been suggestively stated by Mr. W J McGee from observations on the Papago country. ${ }^{x}$ The conditions of the desert are such as to produce remarkable adaptations and many aberrant forms. In the hot air and long drought, a rapidly transpiring plant would soon wither and die, hence on the desert flora there is a marked absence of foliage. Leaves are small and tightly curled or else greatly modified, as in the yucca, agave, and cactus families. Verdure pervades the permanent body of the plant, giving a uniform green tinge to trunks and stems. Many adaptive devices for storing water are to be noticed: the pulpy, robust trunk of the great "saguaro" or the "pitahaya," the broad, flat-jointed stalk of the " nopal," the hollow stem of the "opuntia" are all reservoirs, containing large amounts of hoarded moisture. Protective modifications are universal. All the typical plants bristle with spines and thorns, a prickly armature guarding every leaf and stem. Other forms exude a hardening lacquer, which frequently covers seeds as well as bark. Others cover themselves with a sticky gum or are furnished with a stiff pilage or are roughly furred to catch every drop of the scant rainfall or dew. The more tender plants shrink and hide away beneath their formidable congeners.

On the other hand, all species of fauna assume protective coloring. The gray body of the coyote slips away from view and quickly loses form against the parallel shades of volcanic rock and sand dune; the mottled backs of the small lizards are hardly to be distinguished from the gravels on which they lie. Beautiful examples of coloring and protective mimicry are to be noted in the beetles and other insects of the desert. Another class of desert fauna, the deer, the antelope, the jack-rabbit and the coyote, as well as the various hawks that balance over the arid plain, have developed great speed and marvelous staying power. The sluggish creatures, from the rattlesnake and the heloderma to the ant and centipede, have a defensive venom. The little horned lizard, like the plants among which it darts, has an armature of short spines.

Such in general are the characteristics of life everywhere on the southern parts of the American desert. The Colorado desert, the

I American Anthropologist, Vol. VIII, pp. $350 \mathrm{ff}$. 
particular home at present of the Coahuilla Indians, has, however, bizarre features peculiarly its own.

13. This arm of the desert was in very recent geologic time an arm of the Gulf of California. More than 1,600 square miles is still below the level of the sea, the most depressed portion being 275 feet lower than the ocean.

The Colorado river in its course south to the ocean built up a flood plain on a higher level that finally shut off the western part from a direct communication with the sea, and evaporation, with a gradual uplifting of the whole section, finally laid it bare, although leaving a great part of it below the present sea level. ${ }^{x}$

The waters of the Colorado, 275 feet above sea level at Yuma, break through their banks at the summer season of high water and flow southwestward and then northward and inland forming a widely inundated area with many sloughs, the best known being the New river. This formerly took place in sufficient volume to form in the center of the valley a huge inland lake, a vestige of which still remains in the Saline lagoon at Salton.

There are three principal soil levels noticed in crossing the desert: an upper, made of great "alluvial fans," which skirt the western mountain ranges and are formed of great masses of rock, gravel, and detritus, washed by cloud-bursts from the hillsides and swept far out over the sands; mingled with this layer are bits of silicified wood and oyster shells; second, a sandy middle layer, representing the former bed of the sea; and, third, a lower layer of clay or fine silt, laid down in still water and extending for many miles, representing the bed of the former fresh-water lake and subsequent lagoons, that are even now occasionally filled by water from the New river overflows. Over the surface of this latter level are scattered great quantities of fresh-water shells, mostly small univalves Amnicola protea and $A$. longinqua and the Physa humorosa, and a single bivalve, a species of Anodon now found in the Colorado river ( $A$. Californiensis Lea). The physa is also sometimes found, still inhabiting springs on the New river. ${ }^{2}$

The great horror of the desert is, of course, its heat and the absence of water. To venture upon it without a guide, to miss ones way, or to find an expected water hole dry or obliterated by a shifting drift of

IE. B. Preston, California State Mining Bureau, Fourth Report of the State Mineralogist, r893.

2 The desert was first carefully studied and its physiographic characters learned and beantifully described by Mr. William P. Blake, of the Pacific Railroad Survey, 1853. His report on the Colorado still remains the only complete study of this most attractive region. Exploration and Surveys for Railroad Route from the Mississifpi River to the Pacific Ocean, Vol, V. Washington, D. C., 1857. 
sand, means almost certain death. Madness relieves the sufferer of sensibility long before the end comes, and nearly every year lives are thus lost within this fatal area. Springs occasionally peep out from beneath an overhanging boulder or cliff along the mountain side or rise in small pools along the elsewhere dry bed of a stream. These twinkling lakelets are called by the Coahuillas pal-hé-push-em or "eyes of water." Down on the desert, along the dry washes of the Colorado river overflow, are numerous lagoons which hold water for many months at a time, and in certain regions underground seepage is present and may be reached by digging. Such springs are the "Indian Wells," a former station on the Yuma road above Indio, and farther south "Coyote Wells." At Salton, in the most depressed portion of the desert, a lake forty miles long and several wide, rose suddenly in the summer of 1892 , causing considerable consternation and many strange rumors. Investigation showed that there was taking place an unusually large overflow from the Colorado. The excessive saltiness of the water, however, occasioned at the time theories of subterranean communication with the Gulf. It might be stated here that the lagoon at Salton is excessively saline, and having of old been a source of salt supply for the Indians, even from the coast, is now worked by the New Liverpool Salt Co.

The evidence of volcanic action is everywhere present. Volcanic rock and pieces of pumice abound. Black lava buttes and extinct craters, notably the beautiful and perfect crater, below the line, known as the Cerro Prieto,'rise from the plain, and thermal springs are common.

But perhaps the most striking phenomena of any part of the American desert are the "mud volcanoes." These "volcanoes" are found in two regions on the Colorado, one near the south end of Salton sink, the other near Volcano lake in the Cocopah country of Lower California. They first attracted attention and perhaps date from the heavy earthquakes that occurred on the desert in $185^{2}$ soon after the establishment of the military post of Fort Yuma. Those near Volcano lake were noticeable for the heavy cloud of steam they threw off, and were at once visited by Lieutenant Heintzleman, commanding officer of the post. ${ }^{x}$ Later these were visited by Dr. John L. Le Conte, ${ }^{2}$ while those near the Salton sink were well described a little later by Dr. Veatch. ${ }^{3}$ They are rather boiling springs of mud or

I Eмову, Mexican Boundary Survey, Vol. I, p. 105; Pac. R. R. Reports, Vol. V, p. II 5.

2 "An Account of Some Volcanic Springs in the Desert of the Colorado, in Southern California," American Journal of Science and Arts, Second Series, Vol. XIX, May, 1855 .

3 " Notes of a Visit to the Mud Volcanoes in the Colorado Desert in the Month of July, 1857 ," Proceedings of the California Academy of Sciences, 1857, p. 104; republished in American Journal of Sciences and Arts, Second Series, 1858 , Vol. XXVI, p. 286. 
"salses" that have thrown up mud cones three to fifteen feet high about their orifices. Masses of mud with jets of hot water are thrown up, sometimes to a height of many feet, and vapors of water, sulphur, and sal ammoniac are thrown off with eruptive explosions audible for many miles. One of these bubbling mud springs occupies a craterlike depression twenty-five feet deep near the station called Volcano on the Southern Pacific railroad. ${ }^{\mathrm{x}}$

The atmospheric conditions are fully in keeping with the other features of the desert. A temperature in summer during the daytime of I $5^{\circ}-\mathrm{I} 20^{\circ}$ is not uncommon in the coolest and shadiest spot attainable. Owing to the exceeding dryness of the air, however, moisture from the body evaporates very rapidly, and even this extreme heat is not very hard to endure. A large supply of water is, however, for the white man an essential. Through the whole course of the desert, from Yuma to San Gorgonio there rages much of the time a furious storm of wind and sand. Its effects are most curious. The mountains on the northern side of the pass are piled almost to their summits with drifted sand. Enormous dunes collect at this side of the valley and vast stretches of the desert are left as smooth and clean of vegetation as a plowed and harrowed field. The wagons of parties crossing the desert along this one hundred and fifty mile sand-swept line are buried to their boxes every night by the drifted sand piles. The effects of this silica-laden wind are as terrific as a sand-blast. Telegraph poles are rapidly worn away and have to be frequently renewed. The windows of the section houses or pieces of broken bottles left on the sand are soon converted into ground glass.

Rain seldom falls on this desert in a natural manner. When it comes it is in terrific water-spouts or cloud-bursts that flood the country briefly like a lake and cut great gullies, twenty-five feet deep, in the sand. For miles the railroad track is little but a succession of culverts bridging these steep barrancas.

I 4. Some portions of the desert, as we have noticed, support quantities of the mesquite as well as the agave; others are absolutely destitute of any vegetation whatever. Anong characteristic plants are the Larrea Mexicana or "creosote bush," so called because of its peculiar odor. Its leaves are sinall and sticky, and it bears a yellow flower. The "palo verde" (Parkensonia Torreyana) is so named by the Mexicans because of the pale green color of its branches. Its

\footnotetext{
I For a more extended account of these mud volcanoes, as well as of the Colorado overflow, see the present writer's article, "The Colorado Desert," in the National Geographic Magazine for September, rgoo.
} 
bright yellow blossoms hang in long clusters all over the tree and are much visited by bees. The leaves are small, awlshaped bodies, almost invisible; the branches probably contain the stomata as do the trunks of the cacti. The "ochotilla" (Fouquiera spinosa) is one of the most remarkable of desert plants. The trunk is very short and branches into a number of long, whip-like shoots covered with curved spines, an inch or so long. The flowers are bright red, forming clusters at the end of the shoots, and succeeded by oblong capsules filled with minute seeds. ${ }^{x}$ These plants, with stunted greasewood and sage bushes, as well as the different varieties of opuntia and echinocactus, are among the very common and most striking plants of the desert. In the spring a few pretty annuals appear, some bearing beautiful flowers. The dry mountain sides and the cañons above the desert enrich the Indians' ethno-botany with many species of plants which we will notice later.

But the most striking botanical feature of the desert is its cañons of palms. The best known of these are at the southern end of Palm Valley. Here two long rocky cañons are filled for miles with these beautiful trees. Many of them rise forty feet high covered with the persistent bases and sheathes of dead leaves, while at the top they are crowned with long, graceful fronds. These tops droop closely together, filling the narrow cañon from side to side and affording a grateful shade. The approach to these spots is sudden and the sight most unexpected and amazing. Such luxuriant, tropical vegetation would never be looked for in the midst of such sterile surroundings. The pools of water impounded in the bottoms of the cañons explain their presence. Many strange theories have been evoked to account for the existence here of these stately trees. It has even been stated that they have sprung from seed dropped by the thoughtful Franciscan friars, who were supposed to have journeyed through here, but the plant is an indigenous one, the Washingtonia filifera, and the same species, as well as another, are to be found in the Cocopah and Sierra Madre mountains of Lower California, Guadaloupe island, and the Mexican mainland.

15. The villages or rancherias of the Coahuillas, at the present time, are as follows. Their last villages in the San Bernadino and San Jose valleys were bro'ken up thirty years or so ago, and, although they still come to the vicinity of Redlands and Riverside in search of work, their camps in these places are no longer permanent homes. They

I J. F. Jamzs, "The Colorado Desert," Popular Science Monthly, r88x, Vol. XX, p. ${ }_{384}$. 
were driven from the San Timoteo cañon in the forties by the ravages of small-pox, and the first reservation to be met now, as one rides eastward through the pass where they once held sway, is below Banning, at Potrero, a fertile spot, irrigated by the water from a cañon of Mount San Gorgonio. Here live several hundred Coahuillas and Serranos who have considerably intermarried - the ancient antipathy having broken down. A few miles into the desert from the White Water, sheltered on the west by the lofty summit of the San Jacinto and on the east by a friendly spur of the same range, is Palm Valley. About a famous thermal spring there is a little oasis in the sand where has long been located a rancheria of the Coahuillas, known as Agua Caliente. Pushing around the spur that forms the eastern wall of this nook and following the line of the mountains along the old stage road through Indio to Yuma, one comes to "Indian Wells." Fifty years agro, when the Pacific Railroad Survey passed through this valley, this site was a notable village. Mr. Blake in his report comments especially on the wells and the villages here, where the expedition camped. ${ }^{x}$ Now the site has long been abandoned. The burned stumps of the framework of houses stick up above the sand in the openings between the mesquite clumps. Everywhere there are quantities of broken bits of pottery, as tough as when first baked. There are many flat grinding stones for milling seeds and an occasional fine stone pestle, seventeen or eighteen inches long, that was used for pounding mesquite beans. But the Indian occupants have fled.

There is a small village at Indio and a few miles east the very interesting rancheria of Cabeson, furtherest of any across the valley and not far from the slopes of the San Bernadino mountains, in to which the women of this village range for the plants they need. Southward and in the very center of the plain is La Mesa, hidden in the inesquite and with splendid, typically dug, wells. Further on and close under the shadows of the eastern ranges of San Jacinto are Torres and Martinez, while still further on are Alamo and Agua Dulce. These inames, it will be noticed, are Spanish and have obtained universal currency among Indians and whites, but the old Coahuilla place-names are still treasured by some of the Indians. Potrero is Mal-ki; Agua Caliente, Se-chi; Indio, Pal te-z'at ("water and pine tree"); Cabeson, Pal se-ta ("alkali water") ; La Mesa, Temal-wa-hish ("the dry ground", a name often used by the mountain Indians for the desert in general); Martinez, So-kut Men-yil ("deer, moon" so-called, as explained to me

rPacific Railroad Survey, Vol. v. 
by a very old Indian, because it was once a famous place in which to hunt the deer in the moonlight); Alamo, La-veil-van or Si-vel (" cottonwood trees"); Agua Dulce, To-va; Indian Wells, Ka-vi-nish.

Returning to the mountains once more, among the rocks and pines on the south side of the isolated summit of Torres is a rough little valley, traversed by a small, rapid stream, to which the Indians long ago penetrated. Here is the interesting village of Santa Rosa, We-wut-now-hu ("pines"). These Indians make their homes during the winter months in the Coyote cañon, a wide, sandy arm of the desert, thrust in south of Torres. Across this valley is the Coyote range of mountains. Up the sides of these mountains the Coahuillas found their way and established themselves in a beautiful and remote little glade, now known as the San Ignacio (Pá-cha-wal). Cut off on all sides by the desert and high ridges, rarely visited by whites, this village, as might be expected, presents the greatest appearance of Indian comfort and prosperity. The valley is only a mile or two in length, but a stream of water flows through its center, leaving meadows and garden plots on each side; oaks crowd the cañon at its lower end and, although the surrounding mountains are unwooded except with low, impenetrable chaparral and from every point of vantage one sees nothing but the burning sands of the desert, the glade itself is charming; a kind of Indian's Happy Valley.

From San Ignacio there is a steep wagon road leading southward out of the mountains to Warner's ranch. Half-way down the mountain is another pretty valley, San Isidro (Ho-la-kal), where live a few families of Coahuillas. Warner's ranch is perhaps the dividing territory between the Diegeños and Coahuillas. The two great waves of Indian emigration across the desert, Yuman and Shoshonean, appear to touch here. Agua Caliente, the famous hot springs of Warner's ranch, seems to have a mixed population of Diegeños and Coahuillas. The Coahuillas call the village $K o-p a{ }^{x}$

16. The Coyote cañon, which we noticed above, in spite of its sandy appearance, is exceedingly fertile. It receives the small streams from the mountains on both sides of it and these waters, spreading out and sinking into the sand, occasion subsurface moisture. The agave grows here abundantly and grass springs up luxuriantly after every freshet. It is a veritable harvest field for the Indians. Westward from the Coyote rise the ridges of the San Jacinto mountains - rough, barren

\footnotetext{
I "At Agua Calienta," says Taylor, "was a very populous rancheria, called Ha-koo-pin." ("Indianalogy of California," California Farmer, Vol. XIII, p. 9o.)
} 
hills, piled with huge granite boulders of exfoliation, covered below with thickets of chaparral and higher up dotted with juniper trees and other conifers. After twenty-five miles of tortuous climbing a narrow cañon leads one out into the mountain Coahuilla valley (usually written Cahuilla), where is a reservation eight miles in length, the home of the majority of the mountain Indians. The elevation is about 4,000 feet above the sea level or the plain of the desert ; frost occurs at night almost every month in the year and the cold climate is in marked contrast to the heat of the desert. There is little wooded vegetation, the valley being below the pine level. Great boulders are piled everywhere over the surface of the ridges that divide the whole valley into little retreats. There are, however, numerous springs, and the valley is rich with grass. It is in easy communication with the valleys and towns to the eastward, and Pechanga, the nearest village of the Luiseños, is distant perhaps forty miles, but only the rough and dim trails connect this valley with the Coyote, San Ignacio, Santa Rosa, Torres, and Palm Valley, routes almost unknown to the whites.

\section{CHAPTER III.}

\section{HOUSES AND HOUSE-BUILDING.}

I 7. The houses of a Coahuilla mountain rancheria are not grouped in a village, but are scattered about as widely as the habitable portions of the reservation allow. Each family occupies a cluster of little dwellings by itself and near it are usually some attempts at cultivation of the soil. The sites chosen are small eminences or gentle slopes bordering the valley; water is, of course, a consideration, but the spring may be at some distance, from which the needed supply will be brought daily in an olla by a woman. There is a strange quietness surrounding these homes, a quietness frequently saddened by the absence of little children. No loud voices are heard; the ordinary work of the household goes forward awaking but little sound. There is little social intercourse except at times of the feasts, and a strange and sombre loneliness hangs over an Indian village, especially at nightfall. Yet these primitive Indian homes have a charm and picturesqueness all their own. In the desert villages, where the inhabitants are drawn more closely together about the most available source of water, the homes are clustered within a narrower area with a corresponding gain in social advantages. 
1 8. The Coahuilla house, or rather houses, for there are several types, is a rather interesting ethnographical study. The most typical habitation is the jacal. Jacal is a Mexican word in wide use, derived from the Aztec $x a$-calli, meaning a "house of straw." The Coahuilla word for "house" is kish, but an jacal is commonly called samat, a word meaning also the brush and grass from which it is constructed. The most typical jacal is perhaps to be found in the mountain villages. The work of building is done by the men. A quantity of stout poles six to ten feet long and from four to five inches in diameter are cut from the "greasewood," Coahuilla o-ot (Adenostoma fasiculata), which in these mountains attains the dimensions of a small tree. Sometimes for the heavier pieces branches and trunks of the great manzanita (Arcostaphylos glauca), which grows sometimes twenty feet high and has a most beautiful bark of a reddish brown or mahogany color, are used. At other times various species of mountain oak. The site for the home is marked off in a rectangle, perhaps twelve by eighteen feet, or smaller, according to the size desired. The trunks are trimmed so as to leave a crotch at the smaller end. One is then sunk at each corner of the proposed dwelling, leaving about four feet above ground. Midway between each two end-posts is planted a larger, stouter trunk, also crotched at the top and rising eight or nine feet above ground. These six posts form the perpendicular framework of the building, though a seventh may be set up about thirty inches to the side of the central post at the front end, and with it form the sides of the door. Three long poles are then cut and laid horizontally between the corners and central posts, resting in the crotches and forming the ridgepoles and sidebeams. Other poles are put on for rafters, and across these and parallel to the ridgepole are laid many other lighter pieces at intervals of six or eight inches. Ridgepole, sidebeams, rafters, and every piece is bound tightly in its place with green, pliant leaves or fronds of the Yucca Mohavensis. Stakes are driven in along the sides and at the end, then brush of the salix (the willow is called by the Coahuillas sak-hat) is wattled in very close to form the walls, which may then be chinked or roughly plastered with mud-if possible, adobe. For the thatching, the "tule" or bulrush is used. The tule is of well-known importance to the Indians of California. Several species of the scripus are carefully distinguished by the Coahuillas, according to the form of the rush or stalk, by the names pa-ul-em, pang-at-em, $k u$-ut-em, etc. These varieties grow about springs or small cienegas, and are all of them of value for thatching. They 
are spread out in flat bundles and poles are laid laterally across them to hold them in place. Strips of yucca fronds are here also used in binding on this thatching. Other materials used for thatching are various grasses and reeds; in the Coahuilla mountains the Elymus condensatus or pa-han-kis, and the reed Phragmites communis. The walls of the home are called kish-ga-ow; there are no windows in the jacal; the door is $k i$-mil, and is made four and a half to five feet in height and two to three in width. A stout pole fastened across the end of the house above the door makes a lintel for the opening. The aperture may be closed at night by hanging up a rawhide or setting up before it a rude framework of poles, held in place by a brace or a stone or two. For the sake of security many of the jacales are now closed with a board door swung on raw-hide or iron hinges and secured by padlock and chain. The ground inside the jacal is usually excavated a few inches lower than the surrounding level, and is trodden hard so as to form a smooth, clean floor. In the center, beneath the smokehole, which is left in the thatching at one side of the ridgepole, a slight depression, with three or four fire-stones to support the fuel, makes the hearth. The jacal is often banked up with earth a foot or two on the outside.

To accommodate the usual fanily two or three such buildings are needed. These usually face each other about a little patio or court, but one may be joined to the rear end of another, and in such cases is used for the most part as a store-room. The patio, which the Coahuillas call zwa-yi-los, is, except in cold or stormy weather, the meeting place of all the family. It is surrounded by a low brush fence or wall, which wards off the wind and also serves as a clothes line, utensil rack, etc. In summer time the patio is roofed over and partially inclosed by an airy booth, known everywhere throughout southern California by the Spanish word ramada, from ramas, "boughs" or "branches." The Coahuillas call it taish-kish-la. It is the most comfortable of summer houses. The breeze draws through it, keeping it cool and pleasant, when outside of this leafy retreat the sun may be beating with scorching heat upon the valley. It is made square with flat top. The frame work is of light poles, tied with yucca spines, and the roof and walls are of willow boughs.

The admirable features of the jacal can be instantly appreciated. It is easily kept clean and is always well aired. Its only drawback is that it is smoky, especially in wet weather. The rafters and thatching are black and shiny from the soot of many fires. Not the least of its 
hygienic features is the fact that, being easily built, it does not outlast its freshness. As soon as dilapidation appears and the dirt collects in the corners, down it comes and a new one takes its place on a fresh site a few yards away. It is seldom that all the houses of a family are left the same for two successive years.

In the hot months the family usually moves into summer quarters. The patches of maize, melons, and vegetables ripening at this time are likely to be at some little distance from the permanent home. So on the edge of the garden a ramada is built, and here are moved the metates, pots, water jars, and other needful plunder, and a picnic begins which ends only when the supply of garden truck is exhausted.

19. The above description of an jacal is such a one as appears, for instance, in the mountain Coahuilla valley. Form, and especially materials, will vary greatly elsewhere. At Santa Rosa, the houses are made of slabs of cedar from the trees among which the village lies. These slabs are planted upright in the ground to form the sides, the chinks are filled with mud, and the flat or slightly pitched roof is made of poles covered with cedar bark.

In Palm Valley are perhaps the most beautiful jacales to be seen anywhere, for here are utilized the large palm leaves of the Washingtonia fililera. The pole framework is made as usual, but the thatching and sides are made of these beautiful fronds.

In the Cabeson villages the houses are built higher at the sides with roofs sloping much more gently from the ridgepole. A favorite material here is a tall thrifty plant, hang-al (the Artemisia Ludoviciana, Nutt.), which is piled upon the roof and wattled in closely to form the walls. Dirt is then piled on the roof and mud daubed thickly on the sides. Some of these latter contain several rooms built on to one another and are high, roomy, and really comfortable. On the desert the posts, rafters, etc. are, of course, cut from the hard imperishable mesquite (Prosopis juliflora).

20. The evolution of the typical jacal is a little doubtful. Temporary quarters, often erected for a few weeks' sojourn, many summer booths and an occasional structure put together in an out-of-the-way place by some old Indian, suggest that the primitive Coahuilla home was quite different. Such as those just mentioned are generally nearly circular or oblong in ground-plan, and are built by simply setting up two or three crotched poles near together and connected with poles, and leaning around these long limbs and branches. Over this rude framework is piled grass or tule thatching. This is much like the 
"wick-i-up" of Apache or Have-su-pai, and suggests those described in Fray Crespi's Viage, seen on the Los Angeles coast, round and domeshaped like half an orange with a smoke hole in the center of the roof. ${ }^{\mathrm{r}}$

The possible outlines of the old dwellings at Indian Wells are still preserved by the short stumps of posts sticking above the sand. These houses seem to have been made by setting half a dozen posts close together in a rectangle or square and leaning against these all around side-poles and brush, making a circular "hogan."

These facts might suggest that the round structures still in use among the Coahuillas are the only abodes of native origin; the jacal being due to white influence and suggestion. This would be, however, a very hasty generalization. The principles of ridgepole, sloping roof, and upright sides were, with little doubt, derived from the housebuilding of the Colorado River Indians, the Mojaves, Yumas, and Cocopahs. The patterns in the Cabeson and on the Colorado are very similar. The lower sides and more sloping roofs of the mountains were probably developed under the necessity of shedding the rain and snow.

The houses of the Coahuillan tribes on the coast valleys, unaffected by the Colorado tribes, seem to have been of a possibly wholly different type. Mr. Reid says: "Their huts were made of sticks, covered in around with flag mats worked or plaited, and each village contained from 500 to 1,500 huts.",

$2 \mathrm{I}$. The feast booths or ramadas constructed in every village merit a word of description. When intended for local purposes only they are simply large, square, flat-topped ramadas, usually enclosed on only three sides. Such booths exist in many villages for dances by the inhabitants of the rancherias at all times of the year. They will be used also for tribal councils, for celebrations of mass at the rare visitations of the priest, and for other public purposes. When, however, a great annual feast takes place, like that of the Fiesta of San Luis in the Coahuilla mountains, every August, to which are invited not only Coahuillas from every village, but also Indians of other tribes, especially the Diegeños, the ramada is quite another affair. Here a line of connected booths, two rooms deep, is built about the sides of a great court, 200 by 300 feet in area, a structure capable of lodging several hundred persons. It is built of poles and willow boughs and

I"La rancheria se compone de viente casas hechas de zacate de forma esferica a modo de uno media naranja con su respiradero en lo alto por donde les entra la luz y tiene salida el humo." (In Doc. His. Mex., series iv, tom. vi, p. $3 \mathrm{I}_{4}$; quoted by BANCROFT, Vol. I, p. $4 \mathrm{C}_{4}$, note.)

2 “"The Indians of Los Angeles County," California Farmer, Vol. XIV, p. I46. 
affords ample protection from the sun and suitable seclusion. Accommodations in such a ramada are vastly superior to any tent, being commodious, airy, and cool. The construction of the ramada occupies the resident Indians several weeks, but it is usually torn to pieces for firewood during the winter, and a new one is made on a fresh site each recurring season. Nearby are built corrals and feeding racks for the horses.

The Coahuillas seldom build barns of any description, their rough little ponies running loose in all sorts of weather, but pigpens and chicken-houses are made of poles, brush, and earth, and sometimes a circular coop, made of sticks and tules, is perched on a high platform where the fowls will be safe from the coyotes.

Of other forms of houses the adobe is in wide favor: its use having been learned from the Mexicans. As in the jacal, the walls are low and the roof is thatched with the scirpus. Some of the Indians are building rough frame shanties of one or two rooms, in the securing of which they are unfortunately encouraged.

22. The furnishing of an Indian home is simple. At one side of the door within lies the woman's broad metate and her mortar for crushing seeds, both kept covered with a mat or cloth. At the other side of the door stands the brown tinaja or water jar (Coahuilla kowe wo-mal) brought full each morning from the spring. In the center of the floor is the hearth with its few blackened cooking pots; perhaps a beautifully woven baby hammock swings from the ceiling, and in one corner are the saddle and reata of the man. Bunks of poles are sometimes built against the wall, but in the more primitive homes the usual bed is simply an untanned rawhide and a blanket spread on the floor. Supplies of food are kept in earthen ollas or beautiful grass baskets, and pieces of jerked meat and bundles of herbs, together with innumerable household articles, are tucked into the sides of the thatching. There is little to become disarranged, and the interior of an jacal is usually tidy and clean. In the summer the furniture is moved into the patio.

\section{CHAPTER IV.}

BASKETS AND BASKET-MAKING.

23. No single manufactured article is of the same importance as the basket, and for this reason it is considered separately. It is made in a variety of shapes and sizes and supplies many purposes. While 
the manufacture of many Indian articles has now almost ceased, the production of baskets continues uninterrupted.

The Coahuilla basketry is of one type throughout, a type peculiar to the Indians of southern California, Diegeños as well as Luiseños and Coahuillas, a variety of narrow coiled ware. Some fragments of similar weaving have been found in the graves of the Santa Barbara Channel. ${ }^{x}$ But the ordinary basket of these Indians was made of reeds and lined with bitumen. Von Humboldt speaks of the Indians around Santa Barbara presenting the Spaniards "with vases very curiously wrought of stalks of rushes" and "covered within with a very thin layer of asphaltum that renders them impenetrable to water.". Such baskets have been rare finds, owing to their destructibility, and of course their manufacture by the coast Indians ceased many years ago. The story of the unfortunate woman abandoned on the island of San Nicolas when the Indians were transferred to the mainland by the Spaniards and of her rescue fifteen years later by Captain Nidever has been often told. When found she was making such baskets, distribut ing the pitch over the inside of the receptacle by placing lumps of asphaltum in the basket with hot stones and shaking the whole with a rotary motion, causing the melting asphaltum to be distributed evenly over the surface. The daubing of wicker baskets with bitumen or gum is very common among the Shoshone Indians. Water bottles with small necks and well coated are made by the Chemehuevi, the Tehachipi Indians, and others. Such water baskets were once made by the Coahuillas, and are called ka-put-il. Mr. Hugro Reid speaks of the water baskets made by the Coahuillan tribes about San Gabriel.

Their baskets, made out of split rushés, are too well known to require description; but, though water-proof, they were used only for dry purposes. The vessels in use for liquid were roughly made of rushes and plastered outside and in with bitumen or pitch, called by them san-ot. ${ }^{3}$

Such receptacles may still be made at some of the desert villages, but I have never seen any. The Coahuillas make pottery for use about the house, and their need of a water canteen ceased when they stopped their roving and marauding.

24. The making of baskets by Coahuilla Indians at Palm Valley was studied by Mr. Schummacher twenty years ago, and his description

\footnotetext{
IDescribed and figured in Vol. VII, Archceology of the United States Geological Survey West of the rooth Meridian.

2 Essay on New Spain, Vol. II, p. 297.

3 California Farmer, Vol. XIV, p. 154.

San-ot is still the Coahuilla word for gum or pitch.
} 
and drawings are published in the volume on archæology before cited, but the process can still be witnessed by any visitor to a village of Coahuillas or Diegeños.

The Coahuilla basketry is a coiled ware, the foundation of the coil being composed of a narrow bunch of grass, around which is wrapped closely a narrow splint. A small awl is used to punch a hole in the coil next below and the wrap is passed over the upper coil, through the under one, and drawn taut, binding the whole tightly together. The coils are narrow, making five to seven to an inch, and there are in an ordinary basket eight to eleven wraps of the splint in the same distance, although the number varies greatly according to the character and use of the basket and the skill of the maker.

The materials used are several. The grass forming the body of the coil is the Cinna macroura, Kunth (Vilfa rigens of Bolander's distribution). ${ }^{2}$ This grass is called by the Coahuillas su-ul. It is found everywhere in their homes, dried and tied into bundles, but $I$ have found it growing only once, in a torrent-swept gorge in the mountains a few miles above the desert. The materials forming the wrap vary according to the color desired. Wooden splints carefully split from the aromatic sumac (Rhus trilobata, Nutt) are much used. These give a light straw color and are largely employed, not only by the Coahuillas, but by other tribes throughout the southwest. They are also dyed a very deep black by soaking them for a week or so in a wash made from the berry stems of the elder (Sambucus, Spanish sauco, Coahuilla hun-kwat for both bush and berry). The other material is a small bulrush or reed grass (Juncus Lesenerii, Bolander). Dr. Palmer calls it Juncus robustus, Watson. It grows abundantly in cienegas or in damp soil. The scape and leaves are two to four feet high, or more, stout and pungent. A supply of these tough scapes is gathered by the basket maker and cut off at a suitable length. She then takes a rush by one end and with her teeth splits it into three equal portions, carefully separated the entire length of the piece: Each scape thus furnishes three withes. This reed is, near its base, of a deep red, lightening in color upwards, passing through several shades of light brown, and ending at the top in a brownish yellow. Thus this bulrush, in its natural state, furnishes a variety of colors.

On the desert, instead of the sambucus a little green or purplish plant (the Sueda suffructescens, Watson, according to Mr. Jepson's

Inited States Geographical Survey West of the rooth Meridian, Vol. VII, pp. 242-48.

2 This is according to Dr. Palmer's identification of the plant. 
identification) called ngai-al is used for dyeing black. Dr. Palmer identified this plant as the Sueda diffusa. He says :

The Coahuilla Indians of southern California make a fine black dye by steeping a quantity of this plant in water. For coloring their baskets black they take some mature rushes and steep them for several hours in this dye, which is very penetrating, and the color is durable, but it has a fetid, disagreeable smell. ${ }^{x}$

Dr. Palmer also notes a use of the dahlia which I have never myself observed.

Dalea Emoryi; D. polyadenia. Branches of this plant, steeped in water, form a bright yellowish brown dye and emit a strong odor. The Coahuilla Indians, to ornament their baskets, steep the rushes in a dye prepared from these daleas. ${ }^{2}$

25. Basket-making is one of the chief employments of the old women. One will sit down flat on the ground on the shady side of an jacal with her limbs thrust out straight in front of her. She holds her unfinished basket in her lap; at her right lies the pile of grass for the body of the coil and on her left side, soaking in a little pot of water, to keep them pliable, are her variously colored withes. Her only implement is her awl or wish. This was formerly made of a bone or even of a long spine from the opuntia set in a piece of asphaltum for a handle, but now it is made of a nail, rubbed down to a slender point, and the handle is of manzanita wood. The wrapping materials are named according to color. The scapes of the Juncus are called se-il and their red portions i-i-ul. When dyed black they are called se-il-tul-iksh or black se-il. The splints from the sumac are called se-lit and the body grass su-ul. With these materials the good old lady will work cheerily away hour after hour, while perhaps a little grandchild plays softly near at hand and a mess of food simmers in an olla over the low fire. No model or pattern is ever used; the basket takes ready shape under her skilful fingers, and is always symmetrical and shapely, and the intricate regularity of pattern carefully preserved. The ends of the withes are pushed back and underneath, and cut off on the inside.

The patterns are varied and always tasteful. A great variety of formal decorative figures are used: sometimes rather conventionalized representations of men, women, and children, horses, deer, etc., are woven into it. I have a curious basket with figures of the human hand x Dr. Edward PALmer, "Plants used by the Indians of the United States," American Naturalist, 1878 , Vol. XII, p. 653 .

$=$ Ibid., p. 654 . 
in black. The inspection and collection of these baskets is fascinating employment. The eye is constantly delighted with graceful forms and harmoniously arranged colors.

26. Baskets are made in different forms for different purposes, and are given different names. The most comon is the se-whal-lal. It has a flat bottom and gently flaring sides, a depth of from four to seven inches and a width of from thirteen to twenty. These are exceedingly useful. They are filled with all kinds of things : foods, including seeds, grains, and fruits; household utensils and basket materials. The second class are globular in shape, with bulging sides and rather wide mouths. They are quite small, the greatest diameter varying from five to ten inches. These are called té-vin-ge-mal, and are perhaps the prettiest and most carefully ornamented of any. They are used for holding the costura (Sp.) or sewing materials of the women, and also the various small treasures of the family, ornaments, pictures, papers.

The great deep packing baskets are called se-kwdi-vel-em. They are beautiful objects, with a usual depth of about eighteen inches. Their use is principally for packing, and they are carried on the back. Sometimes a pair of rawhide strings, $k a$-wi-ve, are tied to opposite edges to pass around the forehead and sustain it below the shoulders, but usually it is borne in a "carrying net." Such a basket accompanies the woman in all her quests for food. They are also used on the threshing floor and for storing quantities of seeds, grains, and other foods. The chi-pat-mal is a round, almost flat basket, with a diameter of sixteen or eighteen inches, and a depth of an inch or so. Its uses are several. In the first place, it is the proper basket for gathering. The woman beats it full of grass seeds or fills it with elder berries or cactus fruit, and then transfers the contents to the packing basket on her back. It makes also a useful tray, a good platter, a fruit dish, and is of great service in grinding at the mill to receive the meal. It is also exclusively the basket used in winnowing. Finally, there is the basket hat or $y u$ i-mu-wal, an object with a very wide use. It is shaped like a truncated cone, and is made to fit the head. It may be worn by a woman at any time, but especially when a burden is to be carried, when it protects the head from the carrying band which passes around the forehead. It also does constant duty as a dipper, as it is nearly water tight, and as a small mixing pan.

The Coahuillas also make an open basket, woven in loose meshes, like a net, of the unsplit flattened scapes of the Juncus, se-il. These 
are often provided with a bail and so hung up in the house or ramada, and used to contain fruits or vegetables. One will hold about two quarts. They are called chi-pá-cha-kish.

All these baskets have flat bottoms, and will sit upright on the ground. The large baskets running to a point at the bottom, made by the northern California Indians and some Shoshone tribes, are never made by the Coahuillas. The style of weaving that fashions these long cone-shaped baskets is very different from the Coahuilla methods. All these baskets are exceedingly strong and durable. They will last for many years, and frayed portions can be easily replaced.

\section{CHAP'TER V.}

\section{PLANT MATERIALS USED IN MANUFACTURES.}

27. After so many years of contact with white men, and so general an appropriation of modern implements and utensils on the part of many, it is surprising how much Indian ethnographic material remains in use. This would naturally be the case with objects of a ceremonial and religious character, but it is true also that in many Indian homes, especially those of the old people, there is almost nothing, if we except clothing, that is not of native manufacture. These articles are not germane to this paper, of course, except as they illustrate the Indian uses of plants.

An exception should be made in the case of pottery which, although it forms no part of the Coahuilla ethno-botany, has an important place here, since it has probably superseded an earlier use of water-tight baskets. The coast Indians do not seem to have made much pottery, the very rare fragments or potsherds that are discovered being usually attributed to the date when these Indians could have acquired the use or knowledge of its manufacture from the Spaniards. Neither do the Utes and Pah Utes manufacture vessels, and Mr. Coville states that the Panamints do not. All the Indians of southern California of the Coahuilla and Diegeno tribes today make earthen ware in abundance. It has been often inferred that they were taught its manufacture at the Spanish missions. Even Mr. Hugo Reid states that the Indians of San Gabriel learned to make their pots from the friars. ${ }^{\mathrm{I}}$ Nevertheless this is, I think, a mistake. While the Shoshone tribes are not usually or perhaps naturally potters, all the Colorado tribes, except perhaps

I California Farmer, Vol. XIV, p. I54. 
the Chemehuevi, are; and the manufacture of earthen ware was most probably introduced into southern California by the tribes of Yuman stock settling about San Diego or by contact with the Indians of the Colorado. The Coahuillas most likely learned the art from the latter, if they had not already acquired it before settling in this territory. The pottery of the Cabeson valley, in its shape and decorations, is identical with that of the Mojaves or the Cocopahs. Everything, however, points to the conclusion that the pottery now made by the Indians of southern California is a native ware and not introduced by the Spaniards. Its method of manufacture is distinctly aboriginal. The clay commonly available for the Coahuilla potter is a poor, gravelly stuff. It makes only a rough jar. Down on the desert a much finer quality is obtainable. The maker provides herself with a basket of this earth (tes-nit), a basin of water, a board a few feet long, and two little implements used in shaping the jar. One of these is a wooden paddle called a pak-pish; the other a molder and smoother, usually a round pebble with one side well polished, called a pai-whal. ${ }^{3}$ The pot is built up in coils rolled out on the board and added to the edge of the growing vessel. The coil is flattened and worked into the body of the jar by holding the molder on the inside and slapping the exterior with the paddle. This coil method of making was, on its face, borrowed from the basket manufacture and is evidence enough that the art was a native discovery. These ollas, in spite of their rough finish, are perfectly symmetrical. They are polished somewhat on the outside with the smooth "pai-whal." After drying for a day in the sun, they are baked in a shallow pit with a quantity of cow manure. The fire is kept up until a red color is obtained. The fire is allowed to touch the pots in baking, a thing so carefully guarded against in Pueblo pottery-making, and gives the olla various spots of black and brown, which make rather a pleasing decoration in the absence of any other. In the Cabeson valley, however, the pottery is generally ornamented with patterns of dots and lines, marked on with a black mineral earth before burning. These, as noted above, are precisely similar in material, form, and ornamentation to the pots of the Cocopahs of the Colorado desert. Ollas are used for the cooking and storing of foods and large ones for holding water. The soft nature of the pottery allows moisture to exude through the sides, which, evaporating, keeps the water cool. Ollas are called koz-a-mal-em.

Is an evidence that the art of pot-making is a native discovery, the old rancheria sites from the vicinity of Pasadena eastward abound in these smoothing stones. 
Little ones are often made as toys for children. A shallow dish for serving food is called a wa-yi-mal.

28. The Yucca Mohavensis(Coahuilla min-yil) furnishes a valuable fiber for weaving. The pliant, fibrous leaves are soaked and basted until the pulpy part and the epidermal sheath are gone. The fibers are buried in mud to whiten them and are then combed out. From these are made a thick foot-pad or sandal, almost identical with the sort described

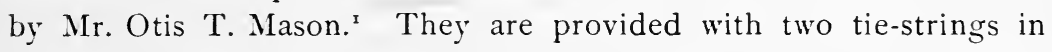
front, one passing between the great and second toes and meeting over the instep, and a loop behind. Such sandals are called wak-ut-em and are still in constant use among the old people. The Coahuillas, to a limited extent only, manufacture the "cocas" or yucca fiber saddle mats, once so much sought after in California by horsemen, but they are still made in large quantities by the Diegeños at Warner's ranch. Dr. Palmer has described the weaving of one on a small primitive loom and with a shuttle. ${ }^{2}$ They are commonly about two and a half by three feet in size, very strongly and durably made, and ornamented tastefully with patterns in brown, yellow, and red. I do not know the plants used in preparing the dyes. A rawhide sandal is also made called push-wow and its strings tack-a-chil. The fibers of the leaves of the "mescal," amul (Agave deserti), make the best cordage and ropes. These fibers are prepared in the same way as the yucca. An old woman will then take a handful, comb them straight between her fingers, wet the end with saliva and twist them into a beautiful cord on her bare thigh. Such cordage is of the strongest. Bowstrings are made of it that last for years. Little brooms and even hair brushes are made from these fibers.

A beautiful cordage is furnished also by the Phragmites communis (Coahuilla wish), a reed with a straight-jointed stalk. These stems are soaked in water and then the bark is easily removed, a layer of soft, silky, yellowish brown fibers. It is twisted into a beautiful and very strong cordage. Carrying nets for supporting a burden on the back are woven from strings twisted from this material, and also, and perhaps more commonly, from the fibers of the agave. The loop is the regular diamond-shaped hammock loop and knot, and is about two inches in length. The head band of the carrying net which passes across the forehead is wound and thickened so as to form a pad. In such a net an old woman will carry a stone mortar, weighing 150 No. "Sandals of the Cliff Dwellers," in Popular Science Monthly, March, 1897, the one figured as 2 American Naturalist, Vol. XII. 
pounds. These carrying nets are used everywhere by Shoshonean tribes, and identical ones are taken from the Cliff Dwellers of Utah and Colorado.

Cord made from the phragmites is called $i-k u t$, the carrying net is to-ko, and the head pad nach-wow.

Splints for coarse weaving and plaiting are made from the fronds of the Washingtonia filifera (Coahuilla ma-zul), the stems of which furnish also a variety of small stirring sticks for mush and flails for beating out seeds.

29. The Prosopis juliflora furnishes a very valuable wood. It is hard and durable and is adapted for various articles. Stools are carved from blocks of it and wooden mortars hollowed from its trunk in which the mesquite beans are pounded to a flour with long stone pestles. The branches of this plant exude also a valuable gum akin to gum arabic. Glue, san-ot, is also obtained from the "creosote bush" (Larrea Mexicana), on the bark of which an amber colored gum is deposited by a small scale-insect. Gum for adhesive purposes is obtained from the white sap of the milkweed (Asclepias fascicularis), and from the Pinus monophylla. Native bitumen is of similar economic importance for pitching and caulking. This mineral product abounds in California under the eastern name "asphaltum" or the Mexican name "abrea." The Coahuilla name is rather a pretty metonymy. Vegetable gum being called san-ot, bitumen is pa-san-ot, or the gum that resembles water. Anyone who has seen the streams of molten asphaltum that issue as bitumic springs from many hillsides in southern. California and in hot weather flow like black sluggish currents for considerable distances would not fail to recognize the figure.

30. The root of the Yucca Mohavensis is grated and these scrapings (called $h i \cdot \cdot n u$-wut) are used for soap. The roots of both $Y$. baccata and Y. agrifolia are, according to Mr. Hough, thus used by the Moki people. ${ }^{x}$ Another soap-plant is of much more frequent use by the Coahuillas, the Chenopodium Californicum. This plant has a long carrot-like root of hard texture. It is grated on a rock and makes a good soap. It is called k̆e-ha-wüt. The valuable soap-root of the coast, the plant usually meant by "amole" (Chlorogalum pomeridianum), which has a large, very saponine bulb, surrounded by a coarse husk of fibers, does not occur in the present territory of the Coahuillas, although in days past, when their ordinary range was wider, they knew its use, and occasionally, now, they obtain it from the San Jacinto plains.

I American Anthropologist, Vol. X, p. 2, 1897. 
31. Like many other Indian women of this section, especially the Mojaves and Yumas, the Coahuilla women tattoo, and for this purpose use charcoal burned from the agave, and prick in the pattern with the thorn of the opuntia. The pattern is always on the lower lip and chin and consists of rows of dots or wavy lines running downward from the mouth. The color is a bluish black. Such ornamentation is called tesh-inum. It is really very pretty but it is not frequently seen any longer among the mountain women. The practice is almost identical throughout this region. According to Father Boscana, who was long stationed at the Mission of San Juan Capistrano, "girls are tattooed in infancy on the face, breast, and arms." 'The most usual method was to prick the flesh with the thorn of the cactus plant, charcoal produced from the maguey was then rubbed into the wounds, and an ineffaceable blue was the result. ${ }^{x}$ Of the Yuma women Mr. Michler wrote: "A very few are tattooed; this operation is performed by pricking the skin with the sharp point of a flint and sprinkling in the wound the dust of charcoal." ${ }_{2}$

32. Beautiful baby hammocks, Coahuilla $i$-kut, are woven from the cord twisted from the phragmites or agave. They are about six feet long and are swung from the ceiling or from opposite corners of the ramada. Frequently the same net is used as a carrying net and a cradle. Baby boards are still used somewhat, though the hammock is preferred. The baby board, si-ul, is made of two upright pieces pierced with holes at regular intervals and in these are set cross pieces, cha-zua-za. A little mattress, in-i-vel, is made now of cloth but formerly of rushes, and laid on this frame. On this the little child is placed and bound securely thereto with a band, su-ti-z'e, passed several times across the body and looped at the sides beneath the projecting ends of the cross pieces. The little bodies are very comfortable and happy in this position. The mother can set the board up beside a boulder while she washes at the spring, or lay it in the shade of the jacal while she grinds at the mill. There is quite a noticeable flattening of the occiput in children that is probably due to the baby board.

33. The Coahuilla bow, dju-ki-mups, is a poor affair nowadays, generally but rudely shaped. The best bows are made from a seasoned limb of the screw bean, kwin-yal (Prosopis pubescens). Others are shaped from wood of the willow tree, or aliso, azea-sil (Salix nigra, Marsh). They are fitted only for killing small game and are produced

\footnotetext{
x Robinson, Life in California, "Boscana," p. 740.

2 Eмory, Mexican Boundary Survey, Vol. I, p. rı.
} 
with an apology and an explanation of the noble weapon made by "los antiquos" (their ancestors). The string is either sinew or cord twisted from the fibers of the agave. Two sorts of arrows, whi-al-em, are used. One is made of two pieces; the shaft of the jointed hollow reed, $p a-$ kal (Phragmites communis), which has a strong culm, five to ten feet high. It grows in wet places and along stream banks and is closely related to the "pampas grass". The end or point of the arrow is made of mesquite wood hardened in the fire, or of the greasewood, sanka (Adenostoma sparsifolium), and is inserted into the hollow end of the shaft and fastened there with glue and sometimes by sinews wrapped around it. Two feathers are attached to the shaft. This two-piece arrow is identical with that made by the Yumas, Cocopahs, Chemehuevi, Mojaves, Yampais, and Panamints. The Coahuillas also make an arrow from the shoot of a species of wormwood, which grows abundantly throughout the Cabeson valley and surrounding mountains, hang.al (Artemesia Ludoviciana, Nutt.). These shoots are peeled, notched and pointed, and straightened with the teeth. This arrow is unfeathered.

The southern California Indians use a rabbit stick, suggestive of those in use among the Pueblos. Among some valley Indians these are flat, curved, and carefully made. The Sabobas at the foot of the San Jacinto mountains, hunt rabbits with them on horseback. The ordinary Coahuilla rabbit stick, however, is rather a small throwing club made of the root and branch of the "chamiso" (Adenostoma sparsifolia). They are thrown with accuracy up to fifty yards. They are called na-hat-em. The Coahuillas once used a war club like those of the Yumas. ${ }^{\text {. }}$

\section{CHAPTER VI.}

THE GATHERING, PREPARATION, AND STORING OF FOODS.

34. The study of those plants which yield sustenance forms one of the most instructive chapters in savage life. The record of starvation and want lies behind the discovery of almost every plant food. The thoroughness with which every grass, stalk, fruit, tuber, and seed, available to the savage, has been examined, treated by fire, by leaching, and by every form of analysis that can be devised, affords us a grim picture of the figure of hunger that is not far from every man.

x Yuma Club, described by LieutenANT MiChler in Mexican Boundary Survey, Vol. J, p. ro8. 
In this work the woman has naturally been the important factor. They have been her explorations, her revolutionary discoveries, the tests made by her teeth and stomach that have advanced the race in its quest for subsistence.

Among the Coahuillas, as among all Indians, the woman is the getter of vegetable foods, the ethno-botanist of her community. Now that the man's hunting has been interrupted forever by the settlements of the whites and the disappearance of the game, the support of the family falls principally on the woman.

The problem of securing food for a tribe within the territory of the Coahuillas at first sight seems an impossible one. It is the ugly barrenness of the mountains and the arid sterility of the plains that impresses one. It is probably true that an untutored white man lost here would be likely to find hardly a single plant to yield him a mess of palatable food. Beauty of flower and foliage and splendor of fruition are alike sacrificed here to the necessities of the desert. There are no luscious fruits with juicy pulps awaiting the thirsty traveler, but at most only shriveled bags of rind filled with seeds, dangling from a dry and ghostly stalk, or small, bitter plums that are nothing but exaggerated pits, surrounded by a puckery skin. In all these mountains there is not an edible root that a white man's efforts would be likely to discover; there are no palatable nuts, except the pinoñes, high in the summits. The absence of food is, however, apparent rather than real. The desert is a kindlier mother than would be expected. Nature is less niggardly here than in some more verdant countries. The flora of American deserts, as pointed out by others, is really quite rich in species. Given the knowledge and patience of the Indian woman, the problem is far simpler than would be supposed. Probably the food supply of the Coahuillas contains a greater variety and abundance than that of most Indian tribes. As we have seen, their habitat occupies the dividing line between the desert and the coast valleys. The mountain Coahuillas can turn westward and meet the flora of the valleys reaching to the Pacific, or descend eastward into the desert and bring back its nourishing and remarkable supplies of food.

35. We have already noticed the se-kwa-vel, or great packing basket. Such a receptacle is the property of every Coahuilla woman. For supporting this upon her back, she has the strong, beautiful carrying net whose manufacture has been described. To protect her head against the weight of her load, she presses down over her forehead a 
$y u$ i-mu-wal, or basket hat, and having slung her net and basket over her shoulder is ready to set out on her quest for food. She has also two other implements, a chi-pat-mal, or flat gathering basket, and her seed fan, $y i$-koze-a-pish. In the Southwest and among many Shoshone Indians, Utes, and Panamints, this seed fan takes the place of the pointed, fire-hardened digging stick of the North. It is shaped like a light tennis racket and is made of willow wands and rawhide. In gathering seeds from the low grass or bushes, the woman holds the chi-pat-mal nearly flat against the ground and beats the seeds from the grass stems with the seed fan.

36. Many of the foods furnished by this country, including several nuts and pits, are bitter and astringent. To remove these principles, the meal ground from these products is leached with water. Sometimes a sandy spot on the creek bottom suffices, but more often a large, shallow basket, perhaps three feet in diameter, is woven of osiers. This basket is set on a low pole platform and filled with carefully selected sand. The basket is called $p a \dot{a}-c h a-k a-v e l$ and the sand $n a$-chish. A depression is smoothed in the sand and the meal piled thereon and water poured slowly through. Contrary to what might be expected, the meal mingles but little with the sand and is daintily scooped out when the leaching is accomplished. A hard, smoothly brushed floor is always to be seen near a home, where various fruits, nuts, and berries are spread out to dry.

37. Of receptacles for storing food, the most striking is the basket granary. These are made of osiers. The withes with the leaves left on are first twisted loosely into a thick rope as big as a man's arm and from this the basket is coiled. The shape is circular, rounding toward the top with a tolerably flat bottom. There is a short, narrow neck. The size is about thirty inches for height and a somewhat greater diameter. The neck and mouth are narrow-ten inches or so across. It will hoid many bushels of grain or seeds. Over the mouth is laid a flat sandstone slab, or a wicker cover weighted with a stone or two. In the Cabeson these granaries are made almost exclusively out of the hang-al, the species of wormwood so abundant there (Artemisia Ludoviciana, Nutt.), and having been filled with mesquite beans they are covered over and sealed with an armful of the shoots and a daub of mud. These granaries are perched either on platforms of poles, or, in the mountains, on the flat tops of high boulders, out of the reach of field mouse or kangaroo rat.

This great basket, or, as the Coahuillas call it, mal-a-not, is the 
characteristic storehouse of these Indians, and is by no means confined to them. The Cocopahs make them in great numbers, filling them each summer with dried mesquite pods and placing them out of reach on the roofs of their houses. Very similar ones are made by the Mojaves. ${ }^{\mathrm{I}}$ Seeds are often stored in old ollas and set away in the corners of the house; many kinds of dried fruit are kept in baskets; often herbs as well as small quantities of dried food are wrapped in pieces of cloth and tucked away in the thatching or sides of the dwelling. This is the regular manner of keeping dried meats or "jerky," strips of which are also hung up uncovered. Hoarding of foods is, however, unfortunately, not a strong instinct with the Indian. For the Coahuillas, as we shall see later, there was not great need of keeping a large supply of food ahead for any part of the year.

38. For preparing the foods for eating, the two most important implements are the primitive mills, the metate and the mortar. The latter is used mainly for crushing seeds, the former for grains. The Coahuilla mortar is a large, nearly round, stone. It is roughly shaped from a hard boulder with a slightly flattened surface for the bottom. In the top is cut a narrow, shallow cavity, perhaps not over three inches in depth. About this hole is fastened with gum a shallow, flaring basket without a bottom, so that the smaller opening just fits over the hole in the rock. This basket-work, thus rising from the edge of the mortar cavity, keeps the grain and meal from falling to the ground, and makes unnecessary any further excavation of the rock. 'The pestle is a thick, heavy stone, perhaps ten inches long, each end being bluntly rounded. In using a mortar the woman sits with a leg on each side of it, takes the pestle in both hands and drops it heavily into the mortar. About a full double handful of grain or seed is crushed at once. To reduce this very fine a few spoonfuls of iron pyrites are tossed into the mortar to assist the milling. This is a practice of which I have seen no notice among other Indians. The pyrites is sifted from the meal when the necessary fineness has been attained. The Coahuilla word for the mortar is ka-zva-val and for the pestle pá-u-ul. The wooden mortars for the mesquite beans have been already noticed.

The Coahuilla metate, called mál-al or ik·ni-vel, is not a particularly well-shaped article. It usually measures about thirty inches in length by twenty in width; the upper end is fully twice the height of

I"Near the houses were a great number of cylindrical structures with conical roofs, quite skillfully made of osier twigs. They were the granaries referred to above, for their surplus stores of corn and the mesquite fruit." (Pacific Railroad Survey, "Itinerary," p. I15.) 
the lower, giving considerable slope to the slightly concave grinding surface, which is increased by resting the upper end on several flat stones. The "mano" or rubbing stone, called $t a k$-ish, is long, wide, and rather thin ; the rubbing surface is nearly flat, the upper side convex. It is held in both hands. In grinding, the woman kneels at the upper end of the metate, puts a little pile of wheat in the middle of the stone and, beginning with the lower edge of the heap, quickly reduces it to a reasonably fine meal. A flat basket, chi-pat-mal, is placed under the lower edge of the metate to receive the flour. Both the metates and the mortars are furnished with neat little brooms made of a handful of mescal fibers (Agave deserti) and called si-yu-vish, with which the meal is brushed from the stone. The grinding is done a little at a time, enough for each day, and forms a regular employment for the women.

A rather curious sifter is used for separating the finer parts of the meal from the coarser, and for removing the iron pyrites grains after milling. The rim is the upper portion of a basket, the bottom removed. Across the smaller opening is stretched a piece of fine woven-wire cloth, obtained from the whites, held in place by abrea. In early times, before the wire cloth was obtainable, I suppose they must have used the fibers of the yucca or agave, or the fibrous covering of the soap-root or "amole" (Chlorogalum pomerdianum), which is used by the Moki Indians for sifting. ${ }^{x}$ The Tulare Indians wove a beautiful basket particularly for a sifter.

39. In methods of cooking the Coahuilla woman is rather limited. Some things are boiled in an olla, a few are roasted among the coals, but almost everything is dried, crushed into meal, and boiled into a mush or "atole." Atole (atolli) is the Aztec word for porridge. The boiled mush served daily to the Indians under the missions went by this name, and thus it was adopted into the various Indian vocabularies. "Pozzoli" is a somewhat richer mush containing beans or perhaps a little pulverized dried meat. The Coahuillas call atole wi-wish-wi-wish.

\section{CHAPTER VII.}

THE FOOD PLANTS OF THE COAHUILLA INDIANS.

40. As already suggested, to the unsophisticated it would seem that the dry and rocky slopes of the desert's sides, with their curious

I James Stevenson, Second Report, Bureau of Ethnology, 1879, p. 335. 
and repellant plant forms, could yield nothing possible for food, but in reality the severe competition and struggle with aridity have operated to invest desert plants with remarkable nutritive elements. The very hoarding of strength and moisture that goes on in many plants is a promise of hidden nutrition. And, while many plants protect their growth against destruction by animals through the secretion of poisonous or noxious elements, the cunning of the savage woman has taught her how to remove these. Beside every Coahuilla home there stands ever ready the wide pá-cha-ka-vel, or leaching basket. The results prove far more than the expectation would warrant.

I cannot pretend to have exhausted the food supply of these Indians, but I have discovered not less than sixty distinct products for nutrition, and at least twenty-eight more utilized for narcotics, stimulants, or medicines, all derived from desert or semi-desert localities, in use among these Indians. To my regret I cannot in all cases announce the botanical name of the plant from which these are derived. A number of these plants, which were seen by me but once, were pointed out and the Indian name and uses described, on a trip through the desert to the Cabeson valley, with a single Indian, Celestin Torte, of Torres mountain, in the summer of 1897 . Some, by their very nature, could not be carried along in the saddle, as we were; a few others, gathered and preserved, could not be identified, owing to damaged condition and absence of flower or fruit. This indeterminateness particularly applies to the numerous species of the cactus family, which grow forest-like over many of the rocky cañon sides of the descent to the desert.

The staples of the Coahuillas are fortunately all determined, some of them having a very wide use among the Indian tribes of the Southwest. It is with a description of some of these staples that we will begin.

4I. On the desert the main reliance of the Coahuilla Indians is the algaroba or mesquite. This remarkable tree is well known to anyone who has traversed the sandy Southwest. Its range is wide, from the desert slopes of the California mountains, eastward in southern latitudes to Texas. Of the Colorado basin it is the characteristic tree. It grows to a height of from thirty to forty feet. Its wood is close-grained and hard ; its leaves small but abundant, and its branches well armored with spines. On the Colorado river and its affluents and overflow streams, the New, and Hardy rivers, it grows abundantly along every slough and about each lagoon. Looking down upon the Colorado desert from the heights below Jacumba pass, the desert appears banded 
with long stripes of splendid green. In the Cabeson valley, far above the level of the overflow, these trees grow in clumps or montes, striking their roots down through the sand to the subirrigation below. Frequently the wind has lodged the sand among these montes, until dunes fifteen to twenty feet high have been built up, covering acres in extent and burying all but the upper limbs of the trees - a curious phenomenon.

The fruit of the algaroba or honey mesquite (Prosopis juliflora) is a beautiful legumen, four to seven inches long, which hangs in splendid clusters. A good crop will bend each branch almost to the ground, and as the fruit falls, pile the ground beneath the tree with a thick carpet of straw-colored pods. These are pulpy, sweet, and nutritious, affording food to stock as well as to man.

Everywhere in the Colorado country, to the Mojave, Yuma, and Cocopah, as well as to the Coahuilla, they are the staple of life. The Coahuillas gather them in July and August in great quantities, drying them thoroughly and then packing them away in the basket granaries. The beans are never husked, but pod and all are pounded up into an imperfect meal in the wooden mortar. This meal is then placed in earthen dishes and thoroughly soaked. It is then ready to be eaten, and is called by the Coahuillas, pé-chi-ta, or mén-yi-kish, according as it is, or is not, sifted. A light fermentation, which shortly results, improves it. The mass itself, while requiring vigorous mastication, is sweet and wholesome. It is sometimes rolled into compact balls and carried for food on a journey. ${ }^{x}$

According to Mr. Havard, this pulp contains "more than half its weight of assimilative principles, of which the most important is sugar, in the proportion of 25 to 30 per cent."

The "screwbean" or tornillo (Prosopis pubescens, Benth.) is less abundant than the algaroba. Its fruit is a cluster of little yellow spirals united at one point. It contains even more saccharine matter than the algaroba, and may be eaten with relish as plucked from the tree. A fermented beverage can be made from this meal and was once much drunk by the Indians of the Colorado river. Major Heinzleman described its use among the Yumas: "The pod mesquite begins to ripen in June, the screwbean a little later. Both contain a great deal of saccharine matter; the latter is so full it furnishes by boiling a palatable molasses, and from the former, by boiling and fermentation, a tolerably good drink may be made."

I Pacific Railroad Report, Vol. V, p. 98.

2 EMORY, Mexican Boundary Survey, Vol. I, p. II2. 
Along the overflowed banks of the New river, and elsewhere about the desert's edge, where cloudbursts or freshets send their sudden streams of muddy water out over the sand, there grows up luxuriantly an enormous species of Chenopodium. In the New river country I have seen the growth higher than a man's head as he sat on horseback. The stalks are sometimes six inches in diameter. The leaves are eaten readily by horses, and the plant is of much value to parties crossing the desert and to stockmen. Its local name is "careless weed." The seeds are eaten by the Indians and the leaves used for greens. Northward, in the Cabeson and Coyote, a smaller and probably distinct species, identified by Mr. Jepson as Chenopodium Fremontii, flourishes after freshets. Its dry branches are covered with seeds which are gathered by the Indians in large quantities, and ground into flour which is baked into little cakes. The Coahuillas call the plant kit or ke-et. After a good harvest of this Chenopodium the edge of the Coyote cañon will be fringed with granaries holding stores of this food.

Another queer little plant that starts up after storm irrigation is the Salicornia subterminalia. Its structure is pulpy and almost leafless. I once found it growing abundantly about Indian Wells. The Coahuillas call this plant hó-at, and formerly used its seeds for food. These seeds were crushed finely into meal on a metate.

42. The most varied stores of food, however, do not come from the fluviatile plain of the Colorado, but from the forbidding mountains that rise high and abruptly on the westward. The character of these ranges has already been partially noted. Their sides are very steep. There are no ranges of foothills or graduated ascents. From the level of the sea at Palm Springs, San Jacinto rises almost sheer upward to a height of /I, roo feet. Only by certain cañons can these mountains be ascended, even by foot climbers. The Ta-quitch cañon that enters Palm Valley is said to be insurmountable. Partly because of this precipitancy and partly because grass and protective foliage are wholly absent, there is little opportunity for soil formation on the desert side. The fragments of rock and soil are swept away and deposited in the great alluvial fans that clog for miles the foot of the cañons.

Nevertheless, the mountains support a bewildering variety of plant life. Nowhere could the relationship of plants to their surroundings be more copiously illustrated. While numbers are few and growth is sparse, the species are very numerous. Most of these plants grow in clumps or communities, and afford illustration of the coöperation and mutual support compelled by the desert. From the lower levels of 
the cañons, by which one begins an ascent, to the summits, where the character of living things suddenly changes, plants and shrubs are met everywhere, growing amid the broken rocks. Curious cacti cover a hillside with an armament of spines, and small annuals dot the sandy levels along the bottoms of the gorges. So it is to these arid but fruitful slopes that the women of the desert plain and the mountain valley both go for food.

Most remarkable of all the plants that flourish in these wastes is the agave, perhaps the most unique and interesting plant of all America. It ranges widely throughout southwestern United Stàtes and Mexico with a large number of species, perhaps one hundred in all; and outside of Mexico, where it furnishes "pulque" and "vino mescal," it is used for food by Apaches, the Pah Ute family, and desert tribes in general. By all these Indians it is prepared for food in much the same way. Several species have become familiar, as the "century plants" of California gardens, but they are not handsome plants, except when in bloom, though they give themselves most beautifully to the wants of the Indian.

The life history of all these species is much the same. They come up in little round heads or cabbages. For years this head enlarges, throwing out fibrous leaves armed with a spine at the point. Even in the hot air of the desert it is twelve to fifteen years before the period of flowering is reached. Then from the center of the plant there starts up a stalk, growing with great rapidity. In the larger species this stalk may be twenty to thirty feet high and eighteen inches through at the base. From this stalk clusters of pale yellow blossoms, thousands in number, open in the hot, quivering sunshine. This supreme act ends the life of the plant.

Within the territory of the Coahuillas there is but a single species, the Agave deserti, Engelm., which grows abundantly along the eastern base of the coast ranges in San Diego county, and southward into Baja California. It was first discovered by Lieutenant W. H. Emory, of the Mexican Boundary Survey, in $1846 .^{x}$ It is a small species with leaves densely clustered, thick and deeply concave, only six to twelve inches long. The scape or stalk is from ten to twelve feet high and slender. The flowers are a bright yellow. From April on, the cabbages and stalks are full of sap and are then roasted. Parties go down from the mountain villages into Coyote cañon for the purpose. Great fire pits or ovens, called na-chish-em, are dug in the sands and lined with

× Geological Survey of California, Botany, Vol. II, p. 142. 
stones. Fire is kept up in the pit until the stones are thoroughly heated; the mescal heads are then placed in the hole and covered over with grass and earth and left to roast for a day or two. Mescal heads thus cooked consist of fibrous, molasses-colored layers, sweet and delicious to the taste and wonderfully nutritious. Pieces will keep for many years. The agave is called $a$-mul, the sections of the stalk, $\boldsymbol{u}$ - $\boldsymbol{a}$-sil, which are also roasted and, though fibrous, are sweet and good, ${ }^{r}$ and the short leaves about the head, ya-mil. The yellow blossoms, amu-sal-em, are boiled and dried for preservation, and then boiled anew when ready to be eaten. The fibers from the leaves of the agave, amu-pa-la, are exceedingly important in manufactures and their uses have been noticed above.

The Yucca Mohavensis (Coahuilla hi-nu-vuit) grows abundantly on various hillsides and sandy cañons of the southern exposure of the San Jacinto range, as well as near the summits of the cañons on the desert slopes. The species is quite different in appearance from the Yucca Whipplei, Torr., which grows so abundantly nearer the coast and in the vicinity of Pasadena, and is known as the "Spanish bayonet" or quijotes. In the Yucca Mohavensis the clusters of spines are very dense about its foot, and its short, thick stump or caudex rises to a height sometimes of six feet from the ground. Its flower stalk or scape is short and thick, but clustered with the delicate waxy flowers of the yucca kind. The fruit, nin-yil, appears as plump, sticky, green pods, three to five inches long with big, black seeds filling the center in four rows. These are picked when green and roasted among the coals. They have a sweet, not unpleasant taste, slightly suggestive of roasted green apples. When ripe, the pods are eaten uncooked and are sweet and pleasant, though slightly puckering to the taste.

The Yucca Whipplei grows but sparsely in the territory ranged by the Coahuillas. Its stalk, called $p a-n u-u l$, is cut before flowering when full of sap, and roasted in sections in a fire pit for one night. The dates or seed bags, wa-wal, are also eaten, as well as the flowers, which when in bloom are picked and cooked in water in an olla. Growing with a clump of agave and yuccas, on the north slope of Torres mountain, I had once pointed out to me a different variety of yucca, probably an unnamed species, which the Coahuillas call $k u$-ku-ul. It is small with slender spines. The head and stalk are roasted and eaten.

I Mr. C. F. Lummis has described roasted mescal stalk as tasting like " jute strings and molasses." "The Apache Warrior," in the Land of Poco Tiempo.) 
43. The variety of trees and shrubs of peculiarly desert characteristics,. which grow over the desert side of the mountains from bases to summits and whose products are made by the Indian to yield food, follow next in our description.

The "ochotilla," or Fouquiera spinosa or splendens, has already been described. ${ }^{x}$ It is a splendid example of desert modification, but its anomalies make it difficult of classification. It grows in clumps on the rocky ridge slopes near the base of the San Jacinto mountains. 'The Coahuillas, who call it o-tos, eat its splendid crimson blossoms, which cluster at the extreme end of its long, drooping branches, as well as its small fruit, which consists of oblong capsules filled with minute seeds. These branches, loaded as they are with thorns, are ingeniously used by the Cocopah Indians far south in the Colorado desert of Baja California in making fences. Two or three of these branches tied above one another between posts makes a barrier through which the most persistent burro will not pass. In this way the Indians inclose many acres of soil, annually inundated by the overflow of Hardy's Colorado river, and subsequently planted to maize, beans, and melons.

In the cañon bottoms as they open out into the desert, grows quite abundantly the "palo verde" (Parkinsonia Torreyana), which the Coahuillas call o-o-wit. Its bright green bark and abundant, though deciduous foliage, make it a handsome tree in the midst of its surroundings. Its fruit is a slender bean, two to three inches long, which the Coahuillas grind and cook into an atole.

The Zizyphus Parryi, Torr., is a very spiny and intricatelybranched shrub, from five to fifteen feet high. It grows about the springs in the higher parts of the cañons, and bears a small yellowish red berry or fruit, which is dry and almost hard. The Coahuillas call this plant 0 -ot and use the fruit by pounding it into meal for atole.

Besides the legumens already described there is a third, whose pod furnishes food, though in somewhat sparse quantities. This is the Acacia Greggii, Gray. In the San Felipe valley, below Warner's Ranch, there is a great deal of it, and a considerable harvest of pods can be gathered by the Indians of the valley. But it does not grow abundantly in the territory of the Coahuillas and is only occasionally used. It is called si-ching-al.

Higher up on the mountains grow two species of wild plum or cherry. One, the Prunus ilicifolia, Walp., has an extensive range

x Supra, p. 32. 
along the California coast and had a wide use among the California Indians. It is called by the Mexicans "yslay" and by the Coahuillas. chá-mish. It grows abundantly in all the cañons of the San Jacinto mountains, its dark, handsome foliage crowding many a pass and hillside. Its fruit is of a reddish-yellow color, and resembles very small gage plums. The pulp is, however, very thin and puckery and the pit preposterously large. It is the kernel of the latter and not the pulp that is mostly utilized. These plums are gathered in very large quantities in August and are spread in the sun until the pulp is thoroughly shrunken and dried. The thin shells of the pits are then easily broken open and the kernels extracted. These are crushed in the mortar, leached in the sand basket, and boiled into the usual atole. The other plum tree has with some question been identified by $\mathrm{Mr}$. Jepson as the Prunus Andersonii, Gray. I found it growing along the eastern summits of the San Jacinto range. Its fruit somewhat resembles the Zizyphus and was formerly eaten by the Coahuillas, who called it cha-zer-kal.

The Prunus demissa, a shrub with a wide green leaf, grows about the springs and moist cañons of Coahuilla valley. Its fruit is a small red berry called $a$-tut.

A small grayish-green shrub, doubtfully identified by Mr. Jepson as Halodiscus discolor, Maxim, is called by the Coahuillas tét-nut. I have never seen the fruit, but the Indians say that though small it is good food.

Before dismissing the truly desert plants that yield food, a word is merited by the palms. These have been referred to above. They grow in long, waving lines along the gorges leading into the desert wherever water stands in pools or seeps through the sandy bottoms. Beneath the wide fronds the dates grow in great clusters, supported by a strong but drooping stalk. These dates are very small and the seeds are disproportionately large, but early in the fall, when they ripen, the Coahuillas lasso the clusters and draw them down for food. Swarms of bees surround the fruit as it ripens, and in the fronds of the palms are multitudes of "yellow jacket's" nests. The Indians of Lower California cut out the heart or center of the top of young palms and eat them with great relish. I have not known the Coahuillas to indulge in these "palmitos."

44. In the valleys near the summit of the range and especially in the Piñon Flats are groves of the Juniperus occidentalis, Hook., low evergreen trees, with thin, shreddy bark. The fruit, a bluish-black drupe 
the size of a small marble, is eaten by the Coahuillas and called by them is-zut.

The acorn was one of the most generally used foods of the Indians of the Pacific coast. Its use was noticed by Cabrillo, the first white explorer to navigate these waters. "They eat acorns and a grain which is as large as maize and is white, of which they make dumplings. It is good food." Certain parts of the coast, the Upper San Joaquin valley and the mountains of the Coast Range are thickly covered with forests of this stately tree. There are no less than fourteen species of oaks in the whole of California and about eight are found in the southern part of the state." Their fruit contains "starch, fixed oil, citric acid, and sugar, as well as astringent and bitter principles." The largest and most palatable acorn is that of the white oak, or Mexican "roble" (Quercus lobata), "common throughout the state, on the plains and in the foot-hills, in the southern part of the state somewhat higher in the mountains." It was mostly from this tree that the Indians of the past supplied themselves.

All the "live oaks" also, among them the Quercus Englemanni, yield palatable acorns. There are several desert and shrub species, $Q$. undulata, Torr., $Q$. oblongifolia, and $Q$. Wislienzi, var. fructescens, the "desert oak" of the Southwest, from three to ten feet high. $Q$. agrifolia, Nee, is the only one of the black oaks affording food to the Indians. It is the coast live-oak of California, the "encino" of the Mexicans. The oak is, however, somewhat rare within the habitat of the Coahuillas and the acorn is not to them of great economic importance. They do not put the same dependence upon it as did the Indians along the coast.

The Quercus dumosa, Nutt., which has a thick, large fruit, grows on the Coahuilla mountain and is gathered in considerable quantities by the Indians of Coahuilla valley. This acorn is called by them kwinyil. It is ground in the mortar and leached in the sand basket. Dr. Havard reports that the sand mixed with the meal by washing has "a decided effect upon the teeth. My informant, a medical officer, tells me that he has seen an Indian forty-five years old with the crowns of his otherwise healthy teeth half gone, while in Indians sixty years old it is not uncommon to see all the teeth worn down even with the gums." ${ }_{3}$ Although the sand basket as a means for preparing food is in constant

x Relacion ó Diario, translation by Mr. R. S. Evans.

2 Botany of California, United States Geological Survey.

3 Food Plants of the North American Indians, Bulletin Torrey Botanical Club, Vol. XXII, No. 3, March 27, 1895 . 
use among the Coahuilla Indians, I have never myself noticed any such effects.

The piñon or pine nut is a very important article of food. The lower limit of the pineries, in southern California, is, of course, high, being almost everywhere about 5,000 feet, and it is only by reason of the fact that the Coahuillas have penetrated into the mountains from the desert that this source of food is available to them at all. The summits of Torres and Coahuilla mountains and the higher San Jacinto peaks are covered with pines of several species; the gigantic sugar pine of the Pacific slope (P. Lambertiana, Dougl.) with a cone a foot and a half in length, the Mexican nut pine (P. Sembroides), and (P. Parryana, Eng.), and also the single-leafed or Nevada nut pine ( $P$. Monophylla), so precious to the Indians of the Great Basin. These nuts are gathered in large quantities, generally in the late fall of the year. Mr. B. H. Dutcher, of the Death Valley Expedition of 189 I has given a careful account of piñon gathering among the Panamints on the west side of Death Valley. $\quad$ The tree was the $P$. monophylla, which has a small cone three inches long. These were pulled and beaten from the trees with a pronged stick and collected in light packing baskets while still sticky with gum. They were then piled on a heap of brush and roasted, which dried the pitch and spread the leaves of the cone. The nuts were then jarred out by a heavy blow from a stone on the apex of the cone. The nuts were winnowed from the chaff by tossing them from a flat basket in the breeze. The Coahuillas harvest the nuts in precisely the same inanner. Sometimes in mid-summer the cones are beaten from the trees, before the ripened harvest time, thoroughly roasted in a fire, split open with a hatchet and the nuts extracted. Piñones are called by the Coahuillas te-wat-em; the cones te-vat, and the little almond-like cavities in which the nuts lie and which are exposed in section when the cone is split open are called he-push or the "eyes" of the te-vat. The pine most used is the Pinus monophylla.

45. The sambucus or elder is of well-known value to the Indians of North America and many are the purposes it serves. The Spaniards in this state fully appreciated it and gave it the name by which it is still well known, "sauco." The Sambucus Mexicana, Presl., is highly" prized by the Coahuillas. By them it is called hun-kwat. Throughout the months of July and August the berries are gathered in large quantities. The little clusters are usually dried carefully on the drying floor and so preserved in considerable amounts. When wanted they

I American Anthropologist, Vol. VI, p. 337. 
are cooked into a rich sauce that needs no sweetening. They are delicious thus prepared. An Indian family during this season of the year will subsist largely on these messes of "sauco."

Several species of the manzanita, an exceedingly handsome tree or shrub with a rich red-colored bark and small ever-green leaves, grow on these mountains. It has a red fruit and is very common. The "great-berried manzanita" (Arcostaphylos glauca) is common throughout the coast. Manzanita is a Spanish word, the diminutive of "manzana," meaning "little apple." / The fruit is much enjoyed by the Coahuillas and is called ta-tu-ka. It is eaten raw and is also dried, pounded into a flour, and mixed with water.

The sumac (Rhus trilobata, Nutt.), the twigs of which are so important in basket making, bears a very small red berry, sel-it-toi, which is very sour but much used both fresh and dried. Soaked in water it makes a refreshing drink. The use of the rhus was noticed by Dr. Edward Palmer. ${ }^{x}$

- 46. Perhaps the most important of the seed foods used by the Indians is the justly famed "chia" (Salvia Columbariae Benth.), called by the Coahuillas pá-sal. The plant is one of the smallest of the sage family. It grows up from an annual root with a slender branching stem, terminated' by several curious whorls containing the seeds. These are dark, round, flat bodies, that have a slippery, uncertain feeling to the touch. The genus Salvia has an exceedingly wide range and use as a food plant. According to Dr. Havard the Salvia polystarchia, Ort., is largely cultivated in northern and central Mexico. These seeds are rich in mucilage and oil. "After careful roasting they are ground into meal, which, when thrown into water, expands to several times its original bulk, the mucilage rapidly dissolving. By adding .lemon and sweetening a very popular Mexican beverage is produced.":

Chia was a staple food with the Indians of the Pacific coast. Large quantities, already parched, have been taken from graves on the Santa Barbara channel. ${ }^{3}$ The seeds are gathered by the Coahuillas with the seed fan and flat basket, and are parched and ground. The meal is then mixed with about three times as much wheat flour and the whole pounded up together. It makes a dark looking meal. This is "pinole," called by the Coahuillas to-at. It is an old and famous preparation. Molina gives the following definition of its constituents as made in $\therefore$ Op. Cit.

2 Plant foods of the North American Indians, Bulletin Torrey Botanical Club, Lancaster, Pa. Vol. XXIII, No. 2, 1896.

3 United States Geological Survey West of the rooth Meridian, Vol. VII, pp. 37, 40, 79, 80, etc. 
Mexico: "Pinolli la harnia de mayz y chia antes que la deslian."” A little sugar is usually mixed with it. In this shape it is a much prized article of food with all who have become acquainted, with its nutritive and reviving qualities. Experienced prospectors and desert travelers carry a little bag of it with them, and when the warm, alkali, water holes are reached, a few teaspoonfuls of the pinole in a quart cupful of the water seems to neutralize somewhat its dangerous qualities and make a refreshing drink more nourishing than gruel..

Pinole, by the Coahuillas, is sometimes baked into little cakes or biscuits. Either way chia is used, it is very good; has a pleasant, nutty flavor, and is exceedingly wholesome. Moreover, it grows in considerable quantity through the mountain ranges of the Coahuillas, and in the early summer ollas stored with these seeds stand in every home, and throughout the cooler hours of the day and evening there is ever a woman grinding at her mill.

Beside the salvia, several other plants yield seeds that attract the Indian woman and keep her busy through the months of May and June with her yi-kow-a-pish and chi-pat-mal. Some of these seeds are very beautiful, and possess a real fascination for the eye and touch. The seeds of the Lasthenia glabrata (Lindb.), called by the Coahuillas ák-lo-kal, in mass resemble iron filings, being of a dark color and fine elongated shape. They are prepared by being pounded up into a very fine flour, which is eaten dry.

But the most beautiful little seed of all is that of the small crucifer called "pepper grass," Sisimbrium canescens, Coahuilla ás-il, a tiny reddish brown seed, round, and flat in shape. It is ground up, cooked in a large quantity of water, and eaten with a little salt.

The Atriplex lentiformus, Watson, one of the "salty sages," is found in the Coahuilla valley and on the slopes of the Sierras. Its seeds somewhat resemble the chia. They are prepared for food by grinding and cooking with salt and water. It is called ká-sil.

The dry flats and valleys of the Coahuilla mountains are frequently closely planted with wormwood, the Artemisia tridentata, Nutt. Its feathery foliage whitens the landscape, and for long distances its pungent odor dominates over every other fragrance. The seeds ripen late in the fall, and are gathered by the Coahuillas and pounded up for pinole. The plant and seed are named by the Coahuillas wik-zut.

47. The flowers or buds, in the case of a number of plants, yield desirable food. The mescal or agave has already been referred to for

I Vocabulario en lengua Castilliana y Mexicana, quoted by BANCrofT, Vol. I, p. 374, note go. 
its many nutritive and useful products. The use of the yellow blossoms, amu-sal-em, of the Agave deserti, has been mentioned above. The flower-crowned tops of the succulent roasting stalks are invariably saved and the splendid clusters of blossoms carried home, there to be boiled and then dried for preservation. I have some, thus prepared, in my possession, that have kept perfectly for five years. They are still sweet and palatable, even inviting to the taste. The incomparable waxy flowers of the Yucca Whipplei are prepared for food in the same way, by boiling in an olla of water.

The use of the sweet scarlet blossoms of the Fouquiera spinosa has also been noted.

The large sumac Rhus ovata, which grows in great clumps throughout southern California and whose broad green leaves ornament many a dingy range of chaparral, has a small blossom which grows in full clusters and is of economic importance as bee-feed. These clusters of the sumac, nák-wit, are cooked in water and eaten.

A species of wild rose, common in southern California, grows along the usually dry washes of the Coahuilla valley and hills. It is either Rosa Californica or ramoscina. It is called ush-ul, and the capsules, $u$ sh-ul-toi, are picked and eaten to a small extent.

One of the most curious ways of preparing food is the treatment of the small slender capsules of the bladder-pod (Isomeris arborea, Nutt.), a shrub with a hard yellow wood. These little pods, so the Indians have informed me, are gathered and cooked in a small hole in the ground with hot stones.

Beside the leaves of the Chenopodium, the tiny dark leaves of the Sueda suffructescens, Watson, whose use as a dye for basket materials has already been noticed, are boiled for greens.

A tall annual plant, unidentified, but called by the Coahuillas ten-il, which has a yellow flower and large leaves, is cooked in an olla and eaten.

One" of the cancer roots, Aphyllon Ludovicianum, Gray, called by the Coahuillas mis-a-lem, grows plentifully in the sandy washes. It has large succulent roots, yellow or white, and in the springtime, before the plant blossoms, and while the roots are young and tender, they are dug up and roasted in the coals for food.

The Astragulus, "rattle-snake weed" or "loco weed," is a genus well known to California stockmen. It has numerous species, somewhat difficult of determination. Several species, at least, are poisonous to cattle and sheep, and it is universally believed to madden horses, dispossessing them of self-control and making them subject to fits 
of ungovernable action, in other words, "locoing" them. One such species, called by the Coahuillas kash-lem, has a curious use as a flavoring principle. By summer-time the leaves fall away from the sere and yellow branches of these plants, and they are covered by quantities of straw-colored pods as big as the joint of a man's thumb. These quiver and rattle with every motion of the air, and give it one of the designations by which it is known. These pods, according to Celestin Torte, are pounded up and mixed with beans, and perhaps other articles of food, as a spice.

48. Among the fruits most important to the Indian inhabitants of the Southwest stand those of the cactus family. There are over fifty species in the United States and a majority of these are found in California.

The Mexican prickly pear or "tuna" (Opuntia Tuna, Mill) is said by Dr. Havard to have been brought to the Pacific coast from Mexico, where it had been cultivated from time immemorial. It was planted in hedges about the missions and ranch-houses, where it thrives still in picturesque clusters and is now thoroughly naturalized. Its fruit is the well-known "Indian fig." While it has not been planted anywhere on the reservations of the Coahuillas, they sometimes obtain the fruit from other Indians of the valleys. The cactus plant is called by the Coahuillas $n a$-vit and the little bud-like fruit $n a-v i t-y u-l u-k u$ or "the little heads of the cactus."

There are numerous species of cactus throughout the mountains down to the desert level. About a dozen yield fruit products utilized by the Coahuillas. In most cases it is the ripened fruit or "fig" that is eaten. In several cases it is the abundant seeds, in others, the buds and succulent joints of stalk. Except in a few instances I can do no more in the way of identification of these species than to give a description of the plant and state its uses and Indian name.

The Opuntia basilaris is an especially valuable cactus plant to the Coahuillas. It is one of the small varieties and has a tender slatecolored stem in flat joints. The young fruit in early summer is full of sweetness. These buds are collected in baskets, being easily broken off with a stick. The short, sparse spines are wholly brushed off with a bunch of grass or a handful of brush twigs. The buds are then cooked or steamed with hot stones in a pit for twelve hours or more. This cactus is called má-nal. Mr. Coville describes exactly the same use of this plant by the Panamints. ${ }^{\text {T }}$ This cooked cactus is, he says,

I Directions for Collecting Specimens and Information Illustrating the Aboriginal Use of Plants. Bulletin of National Museum, No. 39, 1895, p. 6, and American Anthropologist, Vol. V, p. $350,1892$. 
called $n \ddot{a}-v o$. I would call attention to the similarity of this word to the general Coahuilla word for cactus fruit, na-vit. No vocabulary of the Panamints has ever been published, ${ }^{x}$ but they are undoubtedly of the same great stock as the Coahuillas and such verbal similarities are to be expected.

$M u$-tal is another of the opuntia, with flat, ugly jointed stems, growing low and spreading over the ground in the most arid stretches of the valleys. The flat joints, the size of one's palm, are crowded along their edges with buds as big as the last joint of a man's thumb. They are gathered in large quantities, brushed, and dried. They are often stored for subsequent use, and when needed for food are prepared by boiling in water with a little salt and lard. Very frequently also the fruit is allowed to ripen for its seeds. The figs, after being dried, are spread out on a hard, smooth, dirt floor and then the woman sits down beside the pile of cactus heads and with a flail, made from the leaf stem of the desert palm, thoroughly threshes out the seeds. These are then winnowed from the chaff and stored for winter use. Along through the winter, as needed for food, they are pounded into meal and cooked into an atole. These seeds are called wi-al and they are obtained from several species of cactus besides the mu-tal.

There are two cacti growing along the slopes of Torres mountain that in growth and structure much resemble the Opuntia Tuna. I have not seen them in bloom and know nothing of their flowers. Both - yield luscious fruit in large quantities. Ti-nup-em might readily be mistaken for a neglected and stunted growth of the cultivated tuna. $\mathrm{Na}$-u-tem is not so thrifty and grows low on the ground. Its flat stems have exceptionally long spines, two to three inches. The $a-y u-v i-v i$ is a very small cactus, only about four inches high and covered with little hooked spines. It has a very small, sparse fruit.

The cho-kal is a very furry cactus, with round jointed stems two to three feet high. It is light brown in color and grows in communities, sometimes covering a rocky cañon side for a half mile to the exclusion of almost everything else. It throws off extremely disagreeable balls of spines which fasten in a horse's fetlocks and give instant trouble. Its fruit, which I have never seen, is said to be very good.

$U$-a-chim is one of the cylindrical or barrel-shaped cacti, light colored and furry. It has an edible fruit.

Ko-pash is the famed "nigger head," the Echinocactus cylindricis. It appears above the sand simply as a round fluted globe, a little larger

I A Panamint vocabulary has, however, been collected by Mr. Henshaw, but I think nowhere pub. lished as yet. 
than a man's head. It is covered with spines and bears a small edible fig. But its chief value does not lie in its fruit, but in its succulent and thirst-relieving interior. No plant could be more admirably contrived as a reservoir, and the thick tough rind and protective spines enclose an interior that is full of water. This plant is often resorted to by thirsty travelers and, according to the stories told over the desert, frequently saves life.

49. A review of the food supply of these Indians forces in upon us some general reflections or conclusions. First, it seems certain that the diet was a much more diversified one than fell to the lot of most NorthAmerican Indians. Roaming from the desert, through the mountains to the coast plains, they drew upon three quite dissimiliar botanical zones. There was no single staple, on the production of which depended the chances of sufficiency or want. Any one of several much used products might be gathered in sufficient quantities to carry the entire tribe through a year of subsistence. There was really an abundant supply of wild food, far more than adequate, at nearly all times of the year, for the needs of the several thousand Indian inhabitants of former times, although hardly a score of white families will find a living here after all the Indians are gone. And the secret of this anomaly lies in the fact that the Indian drew his stores of food from hillsides and cañons, where the white man looks for nothing and can produce nothing. The territory is a very large one, perhaps 4,000 square miles of cañons and mountains, rough plains, and sandy deserts. In all of it, as we have seen, there are few spots of beauty; only the valleys of pines, the wonderful cañons of palms, and the green potreros about the springs; while over most broods the hot, throbbing silence of the desert. And yet this habitat, dreary and forbidding as it appears to most, is after all a generous one. It bears some of the most remarkable food plants of any continent. Nature did not pour out her gifts lavishly here, but the patient toiler and wise seeker she rewarded well. The main staples of diet were, indeed, furnished in most lavish abundance. Let us notice a few instances. The crops of legumens, that annually fall from the splendid mesquite groves of the Cabeson or the New river country, could not be wholly utilized by a population that numbered a hundred thousand souls. I have seen the mesquite beans fallen so heavily beneath the trees in the vicinity of Martinez as to carpet the sand for miles. Centals could be gathered about every tree. Hundreds of horses and cattle that ranged the valley, to say nothing of the busy women that had crowded their granaries full, effected no visible diminution of the supply. 
In the splendid moonlight, after the heat of the day, from all directions there would come the busy thud of pestle in wooden mortar, as the women worked leisurely at the mills, while jest and laughter broke the continuity of their toil. Every bush or tree was dropping fatness. The desert seemed the very land of plenty, where the manna fell at each man's door.

Or, consider the agave. The various portions of a single plant might keep a family in food for a week. It is a splendid food, delicious, nourishing, and when roasted seerningly superior to deterioration. The lower levels of the cañons of the San Jacinto range or the sides of the Coyote valley could annually feed an army with agave. The "chamish" or "yslay" (Prunus Andersonii) in certain parts of the mountains grows very abundantly and yields splendidly. A single cañon often contains enough to supply an entire village with meal of pounded pits. Within the habitat of the Coahuillas scores of such cañons could be found.

The road from Coahuilla valley down to Ahuanga creek descends along the bottom of a gorge. The sides of this cañon are covered with Yucca Mohavensis. In July or early August these palm-like trees, for so they almost are, are all crowded with stalks hung with heavy pods, more fruit drying in the sun than the entire tribe could devour. 'The groves of oaks and pines in the higher valleys of San Jacinto; the abundant crops of chia and other seed plants; the elder berry, so greatly enjoyed, that frequently families will live for weeks on little else; all of these can be found in inexhaustible quantities. Another fact very favorable to the Indians is the long season over which the gathering of these staples is distributed. The harvest time opens in April, with the budding out of agave and yucca stalks, and from this time until late fall there is no month without its especial product. The chia and other seed plants are ready for the fan in May and June, the wild plums in June and July, the mesquite and sambucus in August, and the piñons and acorns from September on. For only about four months of winter was it necessary to hoard food. The ollas and basket granaries were sufficient store-houses.

50. The uses to which the majority of these food plants have been put are passing away and will not be revived. The Indians are beginning to earn a large part of their support by civilized labor. They are the best sheep shearers in southern California, riding in bands through the country in spring and fall. Many work through the summer in orchards and vineyards and in fruit-drying and packing establishments. 
On the reservations they raise cattle, especially in the mountain Coahuilla valley. They plant maize, beans, peas, potatoes, water melons, squashes and. in the mountains, also wheat and barley. All but the last two require irrigation, and for this purpose they make in the mountains small reservoirs, by damming and deepening the springs, and dig rude zanjas or irrigating ditches. In the Cabeson valley they conduct the water short distances out of the cañons in which it trickles, or at certain villages they irrigate small patches from their wells. The vegetables are boiled or fried; the melons are a favorite fruit, as among all Indians; the barley is cut for hay for the stock, and the wheat is threshed and ground on the metate to make flour. The threshing is an interesting scene. The hay is piled in a small stack upon the threshing floor, a circular, hardened plat of ground, called wa-ki-wanut. Indian boys then ride ponies round this stack, while a man slowly rakes the straw well under the horses' feet. An hour's hard riding will thresh out a good-sized pile. The men then take rakes, wa-kau-zill, and draw off the straw. Rude pitchforks, sal-sal-awit, are also used. Then the women gather up the grain and chaff in large baskets, se-kwa-vel-em. A winnowing cloth, ke-la, is spread on the ground. The winnowing is done in the afternoon, when the fresh wind from the Pacific reaches the valley. A woman fills her chi-patmal or winnowing basket and, standing on the cloth, holds her burden high above her head and shakes the contents slowly out. The chaff is carried away by the wind while the heavy grain falls at her feet. Heads that the horses' hoofs do not thresh out are carefully gathered, placed in a deep se-kwa-vel, and the woman steps in and tramps the seed out with her bare feet. The grain is either stured in the basket granary, mai-a-not, or put into gunny sacks, ków-kwa-nil. Two women will winnow a couple of centals in the course of an afternoon's leisurely work.

5 $\mathrm{I}$. It is an interesting question from what source these Indians first became acquainted with agriculture, the use of irrigation, and with those plants indigenous to America - maize, beans, pumpkins. The California Coast Indians do not seem to have been planters. Cabrillo's Relacion, however, records repeatedly that the Indians told them that there was much maize growing in the interior. But this statement is far from final. They may and they may not have understood one another. He seems nowhere to have seen maize growing or in the possession of the coast Indians, though he noticed their other important foods, the maguey, seeds, and the acorn. 
On the other hand, when the Spaniards discovered New Mexico, they found the Pueblo Indians cultivating maize, beans, and squashes. The Cocopahs and lower Colorado tribes are described by Don Josè Cortez, ${ }^{\mathrm{I}}$ in $\mathbf{1} 799$, as raising an abundance of the above vegetables. So did the Mojaves, Chemehuevis, and Yumas when first seen by American troops and explorers. On the banks of the Colorado irrigation is not needed, neither is any preparation of the soil. The stream simply overflows and leaves rich, damp, alluvial strips along its sides. All that is necessary here is to press a seed down into the mud and leave it alone. In places such as this agriculture will begin if anywhere. Lieutenant Michler reported in $185^{1}$ that the Yumas even cultivated the "seed grass" for food, preparing the seed afterwards by grinding it in a mortar of mesquite wood and kneading the meal into cakes to be dried in the sun. ${ }^{2}$ This cultivation was also carried on far out on the Colorado desert along the channel of the New river, not many miles north from the Hardy's Colorado where the Cocopahs still raise abundant crops on land submerged each summer by the overflow. Along the New river lagoons are village sites where many Indians once lived on the crops they produced, but which have now been abandoned, owing to the increasing aridity of the desert. Dr. Veatch, in 1857 , entering the desert here from the California side, stopped at a lagoon not far from the Salton basin, where his guide, a Diegeño Indian, told him

that this secluded spot was his early home. He was born here and the tribe he now rules over here had their lodges and lived in abundance on the maize, melons, and frijoles that he described as growing here with a luxuriousness unknown to any place away from the so-called desert.

These same facts are recorded by a correspondent in the Alta California of November, $185^{8}$, and have been also related to me by Diegeño Indians now living in Jacumba pass, just south of the American boundary line in Lower California. Their retirement from the desert seems to have been about seventy years ago, and was due to an interruption of the overflow into the desert of the Colorado, which was not regularly resumed until 1849 . It would now be possible to resume life once more along the New river channel, if there were Indians to make the move. Now, it is only a few miles north from here, about the base of the San Jacinto mountains that the Coahuillas have long lived. Here they have cultivated maize and frijoles for certainly a

\footnotetext{
r Report, date 1799, translated in Pac. $R, R$, Nar., Report on Indian Tribes p. I17.
}

2 EMORy, Mexican Boundary Survey, Vol. I, p. 112. 
great many years. It is easier to imagine that the knowledge of agriculture with the seed of corn, squash, and bean came to them long ago across the desert, than that they learned of these things only in this century from the Spaniards. Westward of the Coast Range, however, where artificial irrigation is necessary, cultivation of the soil may not have preceded the missions, although Mr. Taylor years ago made interesting mention of finding on the Sesepe river, near Piru, "remains of ancient acequias or irrigating canals, made exactly after the plans of those of the Gila, covering a space of some four hundred acres," and which he suggests is "the only thing of the kind to be met with in California." I

In concluding this paragraph I cannot forbear calling attention to the fact that changre of diet is not an unmixed good. Doubtless it is an inevitable change, but it has wrought havoc in the health of many families. The transition from a plain atole to a mess of hot food, fried in grease, is more than an Indian's constitution can abide. I believe the heavy mortality among children, the decay of teeth and skin eruptions that are appearing, are due in large part to the aban. donment of native foods for those of civilized life.

\section{CHAPTER VIII. \\ DRINKS, NARCOTICS, AND MEDICINES.}

52. The preparation of cool and refreshing drinks from the fruit of the prosopis and the aromatic sumac has been noticed above. The flower of the "ochotilla," or Fouquiera spinosa, is used also to prepare a sweet beverage by soaking the splendid scarlet blossoms in water.

Of these three beverages the mesquite drink is most commonly used, indeed, during the hot summer months it is drunk continually. A wide clay basin, containing a mass of half-crushed pods of the algaroba is kept filled with water, and everybody helps himself to a good draught as thirst impels. The screwbean, however, as stated previously, makes the better beverage.

Besides these cooling summer drinks the Coahuillas have a tea plant that is very much prized. This is the Ephedra Nevadensis, Wats, called tí-tut. This ephedra grows along the mountains facing the

I California Farmer, Vol. XVI, No. 15. 
desert, and is especially abundant within the territory of the Coahuilla on the slopes below Piñon Flats. It is a shrub of three feet or so in height. The branches and twigs are greatly multiplied, while the leaves are almost entirely absent, being reduced to mere sheathings about the twigs.

The ephedra has, I believe, well-known medicinal properties; certainly the tu-tut is much valued by the Coahuillas. Bunches of these twigs are almost universally to be found tucked among the thatching of every jacal or packed away in basket or olla. The tea steeped from it forms a pleasant and refreshing beverage.

Coville, in his notes on the Panamint Indians, reports that they use the seeds of the Ephedra Nevadensis, roasting and grinding them and making them into a bitter bread. ${ }^{x}$ I have not discovered this use of the seeds by the Coahuillas.

Another shrub which yields its twigs for tea, but which I have never seen growing, is called ta-tu-ka. It would seem important to determine the species of this plant, but it is impossible to identify it from the dried specimens in my possession.

The Simmondsia Californica, Nutt., is a large shrub which bears a very curious nut. It is inclosed in a sheath and is about a half inch in length. It splits in half in such a way as to resemble closely a coffee berry, and it is by this name that it is locally known. Dr. Havard says that these nuts yield a very fine oil, and that the "Indians of southern California use them as an article of food." The only use to which they are put among the Coahuillas, who call the plant ków-a$n u k-a l$, is in the preparation of a beverage. The nuts are ground and a "coffee" made by boiling the meal.

53. Tobacco, as is well-known, is a native American product, and its use among Indians nearly universal. There are several species indigenous to the Pacific coast. Nicotiana quadrivalvis, var. multivalvis, Gray, is said by Douglass to have been cultivated by the Indians of the Columbia river. $N$. plumbaginifolia, Torr., is the wild species used, according to Powers, by the Neeshenams of California, and $N$. attenuata by the Klamaths, according to Schummacher. $N$. trigonophylla, Dun., $N$. Bigelovii and $N$. attenuata were all used by the Indians of Arizona, Utah, New Mexico, and southern California, according to Dr. Edward Palmer.

$N$. attenuata, Torr., grows plentifully in the territory of the Coahuillas. It is quite a tall plant, two feet or so high, with gummy,

I American Anthropologist, Vol. V, p. $35 \mathrm{r}$. 
repulsive leaves and a showy flower. Occasionally an acre or so will be sprinkled with this helpful little weed. The Coahuillas call it pivat-isil or "coyote tobacco," to distinguish it from the "pivat" of the whites. It is still smoked, but its use is disappearing in favor of the cultivated article. Formerly it was prepared by being pounded up in small stone mortars, especially kept for this purpose, mixed with water and chewed.

Two varieties of the milkweed, Asclepias, furnish a curious product. The white sap in these plants, which exudes freely when its stem is cut, is collected by the Coahuillas in a cup and set aside for one night to solidify. Sometimes it is heated over the fire. After being thus coagulated, it is chewed. Its bitter taste disappears after a little and a tasteless gum is left which affords inexhaustible satisfaction to the user. One of these varieties, Asclepias erosa, Torr., is called ke-at; the other, which has a red flower, the species of which has not been determined by me, is called wich-sal. The prepared gum is chil-se.

The passion for intoxicants among Indians, as is well known, is strong. Havard, in his monograph, cites a number of plants used by them as intoxicants or delirients. The Coahuillas, in their native state, seem to have been quite largely free from the use of such drugs. They did not, so far as I can learn, ever distil or ferment the agave, as did the Apaches in the manufacture of their "tiz-win." There is one plant, cited also by Havard, which contains a very poisonous element, which was used by the Coahuillas to produce delirium. This is the Datura meteloides, which they call ki-ki-sow-il. It is a small repulsive annual with a broad leaf and for fruit a large burr. The whole plant is, or formerly was, pounded up, mixed with water and drunk in small quantities, which produced the stimulus and eventual unconsciousness desired. It evidently contains an active poison, and, according to the Coahuillas, used frequently to produce death. It is now almost wholly avoided. Havard says of it that it was smoked and added to intoxicating drinks by the Colorado river and Pah Ute tribes.

The appetites or cravings which lead men in all parts of the world to indulge in stimulants is a very curious physiological phenomenon. Its real basis does not seem yet to be fully understood. The wide comparison of the use of such principles or drugs should assist in determining the nature of alcoholism and attendant morbid appetites.

54. Anyone whose fortune it is to associate at all intimately with almost any of the Indians of North America must shortly become aware of the intensity of their religious feeling and experience. The 
Indian appreciates thoroughly the mystery of life and the reality of the unseen. A large part of the training of an Indian and much of his mature exertions is devoted to the cultivation of spiritual emotions. The student of Indian society has come to understand that chieftainship in a tribe rested not alone upon skill, courage, and resourcefulness, but also upon the reputed strength of a warrior's "medicine."

The discussion of the Indian shaman's position and practice forms no part of our subject and is referred to, as is also the temescal, merely to introduce our study of remedial plants and herbs. Suffice it to say, that the medicine-men among the Coahuillas seem to form a special class, having undergone a preparation and initiation that makes them exorcists and men of influence for life. They are still common and keep up their practices although most of the mountain Coahuillas are nominally Roman Catholics. They operate on the sick in the manner common throughout America, by prayers, barkings, coughing, biting the flesh, and occasionally pretending by sucking to draw foreign substances from the body. Their practices appear to be often successful, relieving the patient's mind and assisting the restoration to health. Father Boscana, who described the practices of medicine-men at San Juan Capistrano, related that their cures were frequent and only to be explained by witchcraft. ${ }^{\mathrm{x}}$

55. The use of the sudatory or sweat-house, well known throughout California by the Aztec word "temescal," was formerly very common in the Southwest and California. For a considerable number of complaints its effects were doubtless beneficial, and the general health was probably improved by it as well. Foreigners have generally marveled at and derided this institution, but except for injury done to the eyes by smoke its effects are pleasant and comforting, and the cold bath which invariably followed the sweat reduced the body to a normal condition and to a healthy and vigorous organization could do no injury. But the use of the temescal for the fearful, infectious plagues, as small-pox, was, according to all accounts, very injurious. Resort to it when affected by these diseases invariably resulted fatally. This result may have served to discredit the practice, for it is no longer customary in any but a few remote Indian villages. There is a temescal at Puerta la Cruz, near Warner's ranch, one at San Isidro, and one in the Coyote cañon. There is also an abandoned one near La Mesa in the Cabeson valley, with a dry well at hand. Other than these I know of none in use in southern California. Those at San Isidro

I Chinigchinich, p. 312. 
and Coyote cañon are still considerably used. The Coahuillas call the temescal hash-lish. They build the house above ground. Two crotched posts are set up about ten feet apart, a ridgepole added and then logs are leaned about it from all sides so as to form an elliptical hut, with a low door on one side. Brush and soil are firmly compacted all over the sides so as to inclose tightly the room. Into this the Indian, when afflicted with cold, grip, fever, or like complaint, and frequently when no illness is felt at all, enters, and building a fire in the center of the hut squats for an hour or two in the heat and smoke. The result is great perspiration. This is followed by a cold plunge or bath in adjacent pool or stream.

56. The Indians of California appear to have had a knowledge of medicine and remedial treatment far in advance of most tribes of North America. Many of their practices show a considerable understanding of the nature of the complaints they were designed to relieve and were unquestionably beneficial.

An interesting review of this system of native therapeutics has been made by Dr. Cephas Bard, ${ }^{\mathbf{x}}$ in which many customs cited in Bancroft's Natice Races are verified out of the writer's rich personal experience in the practice of medicine among both Indians and Mexicans, for many years in this state.

Powers also, in his Indians of California, gives good-sized lists of plants utilized for medicines.

The patient quest for food, the minute examination of every growing thing to disclose a possibly useful property therein, has discovered to the Coahuillas a number of remedial herbs. These are put into use as often as any complaint which they are known to relieve appears, and $I$ have known some of them to be tried by white men with reputed benefit.

Perhaps the largest number of these remedies are purgatives or laxatives. These qualities in certain plants would be likely to be soon discovered by the investigator, and there is a certain necessity for the use of these principles, as several of the staples of food, like the mesquite bean, appear to produce constipation. The Adenostoma Sparsifolium, Torr., the greasewood or chamiso, so abundant on the hillsides of southern California and a really handsome tree or shrub, with yellowish green or reddish bark and fragrant flowers, has been already noticed as furnishing food in its seeds and as of great use in building and for fuel. The twigs of this sankat, as the Coahuillas call it, are dried and 
steeped in a drink to produce vomit and bowel relief. It is of very common resort for pain in stomach or intestines. These twigs are also ground very fine, mixed with grease, and used for a salve.

A strong, black decoction of the leaves of the "wild buckwheat,". Eriogonum fasciculatum, Benth., called by Coahuillas hú-la-kal, is drunk for pain in the stomach and also for pain in the head. The white flower of the buckwheat, so well known as "bee-feed," is steeped to make an eye-wash.

The wormwood, Artemesia tridentata, Coahuilla wik-wut, is used for stomach complaints in the same way as $h u$-lu-kul.

The leaves of the "creosote bush," Larrea Mexicana, a-tu-kul, obtained from the desert are steeped and drunk for bowel complaints and for consumption.

The Perezia microcephala, Gray, an herb two or three feet high, with thin oblong leaves and purple flowers, called by the Coahuillas $h a-b a k$. $a-b a$, is used, when prepared as a decoction, to produce a very quick passage of the bowels.

The root of an undetermined plant, called chi-vi-ni-vish, is cleaned from just where it branches into the stem, pounded up, boiled into a dark draught, and used to alleviate any sort of pain.

The balsamic leaves of the Eriodyction Californica, a low shrub, very common throughout southern California, are reported by the "Botany" of the Geological Survey of California to yield a tonic when infused in spirits. When merely steeped in water this herb makes a strong and not unpleasant tea, sometimes used, within the writer's remembrance, by white families. The Coahuillas commonly use the leaves of this herb, which they call tan-wi-vel, for a poultice or liniment. The leaves pounded up are bound upon the sores of both men and beasts and a strong decoction is used for bathing sore parts or the limbs when painful or fatigued.

The leaves and twigs of the Aplopappus Palmeri, Gray, Coahuilla $h \breve{e}-n i l$, are bound upon the feet, together with hot stones, to relieve swelling and pain.

An eye-wash is prepared by steeping the leaves of the Baccharis glutinosa, Pers., called pa-ki.

Another plant, whose species or genus could not be determined from my specimen, named by the Coahuillas $k i$-ta-vel, is beaten up, root and all, and applied as a liniment or poultice.

Besides the Larrea Mexicana in consumption, several other plants are used for coughs, pain in the chest, and phthisis. 
A tea of the leaves of the sumac, Rhus ovata, Coahuilla nák-wit, is drunk for coughs and pain in the chest. So also are the twigs of the Bigilovia graveolens, Gray, Coahuilla těs-i-nit, a shrub with a wide range, but found in this case on the desert.

For fevers the Coahuillas use the root of a plant called by them $s \breve{e}-v i-t \bar{u}-k i$, which is crushed and boiled, the liquid being then used for bathing the face, neck and hands; a very little may also be drunk.

The above enumeration covers pretty well the scope of native pathology; bovel and stomach complaints, coughs, colds, and mild fevers, sore eyes, occasioned by the smoke of jacal and sweat-house, sprains, muscular soreness and injury, with occasional rheumatism. These were their only diseases before the introduction of the contagious and specific maladies of the whites. Of these latter, by far the most destructive is tuberculosis, which is constantly active and frequently removes a whole family of children. Measles, whooping-cough, and especially small-pox, have been terrible scourges at times. Venereal diseases among the Coahuillas, thanks to their isolation and a saving distrust of the white man, who is never admitted to their community life, are practically unknown. In this last respect $\mathrm{I}$ believe the Coahuillas are superior to almost any tribes of the Southwest.

57. Several medicines also are applied to sick stock.

The Larrea Mexicana is not only used for consumption, but is given to horses with colds, distemper, or running at the nose.

A drink prepared from the Adenostoma fasiculatum is given to sick cows.

At Cabeson I was once shown a bundle of dried roots, gathered in the San Bernadino mountains, called $t e^{\prime \prime}-a$-il, from which was made a medicine for horses.

'The most serious affliction from which horses suffer is, however, saddle-gall. The California stock saddle is the most efficient riding seat, for all practical purposes, ever devised, but though designed and constructed with extreme care, it is unpreventably hard upon a horse's back in the unparalleled exertions incident to western stock raising and mountain riding. The saddle-tree is heavy and the strain of pulling with a reata from the pommel in handling cattle is very hard on the back and hide. The heat in summer is great and horses are ridden harder and more continuously than perhaps anywhere else in the world, sixty to eighty miles on a stretch being common for a good horse and rider. It invariably results that a saddle horse is marked by patches of white hair on withers, back, and sides, that cover the scars 
made by saddle-tree and cinch ring. The various herbs, valuable for liniments and washes described above, find thus frequent use in the cure of saddle-gall.

A curious poultice for such saddle sores is made of the root of the "mock orange," Cucerbita perennis, called ne-kish. This is crushed and mixed with sugar and applied to the wound.

Is-wa-chai-al, the mistletoe, that grows abundantly upon the juniper, is dried, pounded up into a flour, and sprinkled as a powder into such wounds.

The worst saddle-gall I ever witnessed was received by the pony of a Coahuilla Indian with whom I made a trip in 1897 from the Coahuilla valley across the Cabeson, descending from the mountains by the trail north of Torres peak. His horse was a small black bronco of not more than $75^{\circ}$ pounds weight, and as tough as new raw-hide. Its back began to be sore, however, the second day and in spite of every care grew daily worse. By the time we returned to the mountains the animal's withers were swollen as large as a man's head, and a sinus as large as one's forearm, discharging pus, extended down each shoulder to the breast. The last day of mountain climbing the horse was completely disabled and fell repeatedly, banging his nose and head on the trail. In this extreme juncture the Indian relied for a remedy upon the intoxicating Datura meteloides, hunting the obnoxious weed in the storm-swept gorges. He crushed the entire plant between two flat stones, wet it still more with water and rubbed it into the sores. He said it was very strong medicine and would relieve a gall when all else failed. He said further, that as a delirient it was used with extreme danger, that his father, who is a medicine-man of Santa Rosa village, had known four men to die at one time from indulging in it.

Unlike the practices of the medicine-men, this knowledge of the plants to be used in sickness is common to all and peculiar to neither class nor sex. The knowledge in these matters is greatest, of course, in the old men and women, but the good effects of some herbs are known to every child.

This wisdom is only a part of the race adjustment of this people to their chosen home.

58. The Shoshones have not been estimated highly by ethnologists. According to Brinton, Virchow found some of them the lowest in skull-form of any tribes of the continent. ${ }^{1}$ Whether or not the Coahuillas are really superior to other tribes of Nevada and Utah I

I Races and Peoples, p. 256. 
cannot, from comparative observation, say; but I am certain that from any point of view the Coahuilla Indians are splendid types of men and women. Physically they are handsome, often large of size, many men six feet and over, with splendid shaggy heads, and faces of much command and dignity. Their desert home has given them great powers of endurance and enormous toleration of heat and thirst. With rare exceptions, and those always yougenge frequented the settlements, they are absolutely honest and trustworthy. Unlike the Mojaves or Cocopahs they know nejer titution. Their homes and persons are orderly and clean. The fine pools and springs of warm inineral waters which are common throughout their habitat are most gratefully prized possessions. Probably not less than two centuries ago the ancestors of these Indians entered the great range of territory still occupied by their descendants. They came from the deserts north of the San Bernadino range and the stock to which they belong is a desert people, but the Colorado valleys and surrounding mountains raised new difficulties and offered new opportunities. Their adaptations to these conditions, their utilization of whatever was there to be secured, raised their standard of culture until, as it seems to me, it will compare favorably with that of any Indians of western United States, save the Pueblo builders. After having explored with some completeness the various portions of their country and realized the difficulties attending life in certain portions, and the call upon courage and endurance that the desert always makes, the knowledge gained by this people, the culture they attained, apparently long before seen by white men, seem to me to be a remarkable triumph for men of a low, barbarous inheritance.

Their splendid wells, unique perhaps among the Indian tribes of America, their laborious though rude irrigation of the maize, their settled community life, with its well-built houses and basket granaries, their effective pottery, their exquisite basketry, their complete and successful exploitation of all the plant resources throughout hundreds of square miles of mountains and plains, these are not insignificant nor contemptible steps toward civilized life. Several of these arts, especially agriculture, doubtless were borrowed from the Colorado river tribes, or from the New river dwellers; but their utilization, under physical conditions so much more difficult than the fertile irrigated plains of the Colorado overflow, may be regarded as a step in advance.

These things suggest how decided is the influence of the desert 
upon culture, and throw light upon the reason for the origin of the indigenous civilization of the Nile valley or the deserts of Turkestan.

The desert stops the roving, migratory life, and compels settled habitation by natural or artificial sources of water supply, which is the prerequisite of cultural progress.

The culture of the Coahuillas was a developing barbarism, and it is folly to insist thit it would have made, of itself, no further advances.

- I have been particularly incited to record these memoranda of humar patience, toil, and endurance, because the Indian himself will soon be gone, and the wide wastes, which he alone appreciated and utilized, will be left untenanted.

The decline in this population is extremely rapid. They have been steadily decreasing for several generations, and the end now seems almost in sight. Villages, which ten years ago, when I first visited them, seemed reasonably well inhabited, now number scarcely half as many souls. On every side stand abandoned jacales or crumbling little adobe huts destitute of occupants. A sombre stillness broods over these little communities. Occasionally a woman's figure, bent under her food basket, appears returning over the hills, or a horseman rides in and out among the cattle that continue to browse where jacales and granaries once stood, but there is no evidence of active life or of a population holding its own.

Many of the trails once trodden in quest of food are now abandoned; great stones filled with mortar holes remain along the pine ridges and in the cañons of oaks, where no Indians ever come now to gather and grind their seeds. The trails that connect valley and desert are seldom trodden, and as numbers decrease the Indians less often assemble for summer feast or religious celebration.

So perishes a tribe that once controlled southern California from the Colorado river westward to the Pacific sea. 



\section{UNIVERSITY OF CALIFORNIA LIBRARY BERKELEY}

Return to desk from which borrowed.

Th: honk is DUE on the last date stamped below.

RETURN TO DESK DAY USE N

$$
\begin{aligned}
& \text { LOAN DEPT BORROWED } \\
& \text { RENEWALS ONLY DEL }
\end{aligned}
$$

on the date to last date stamped below, or

Renewed books are subjech renewed.

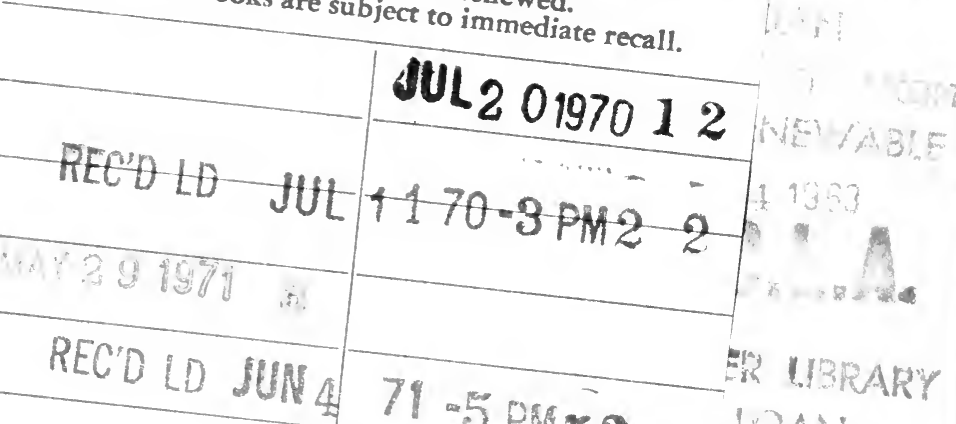

REC'L JUL $+170=3$ PHZ 2

REC'D LD JUN $71.5 P R H^{2} \quad$ LOANARY

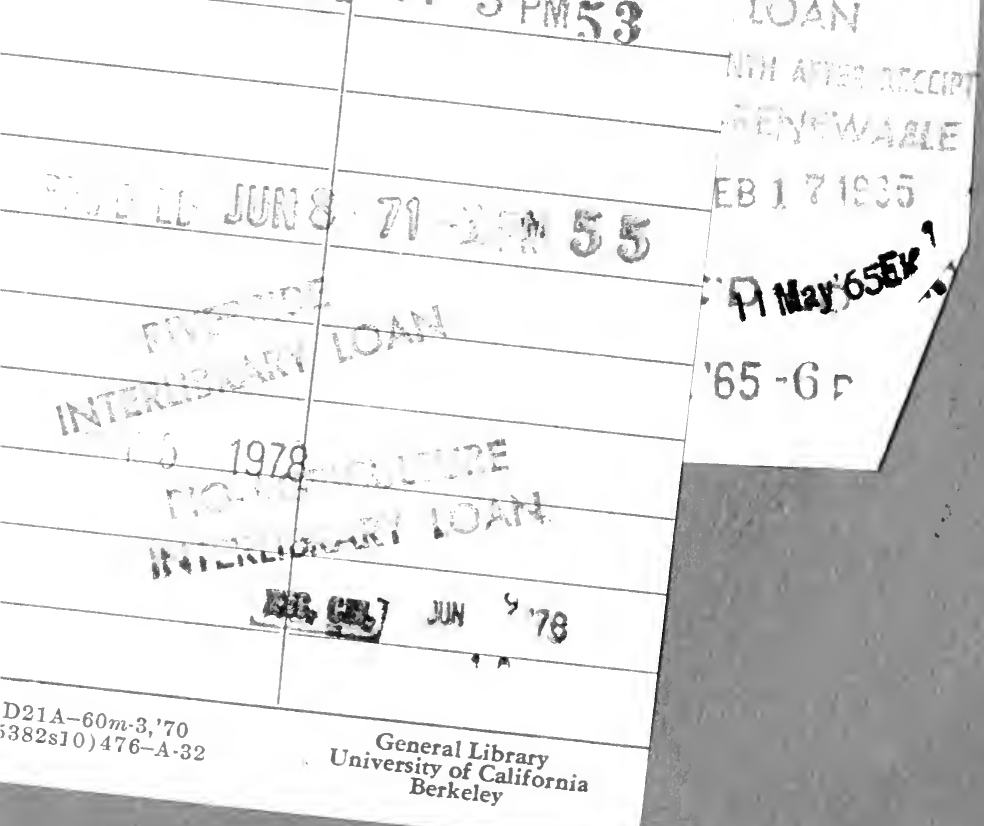


$n$
$n$

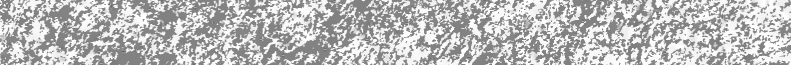

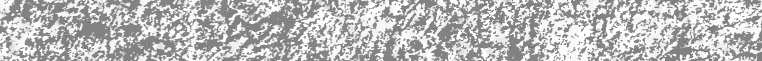

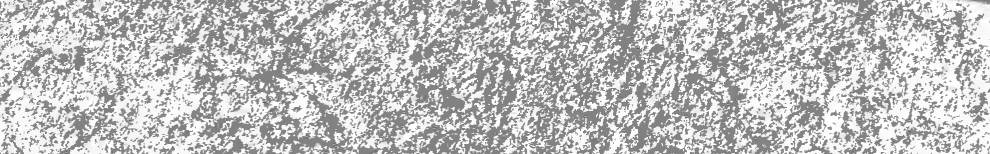

3
A.

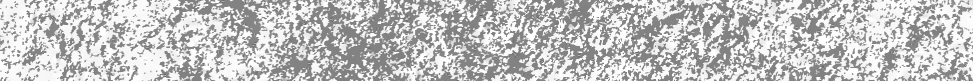

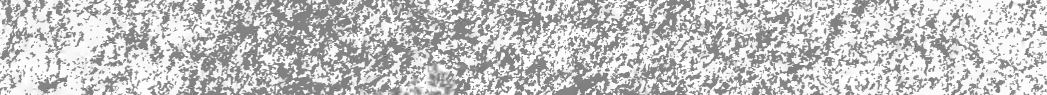

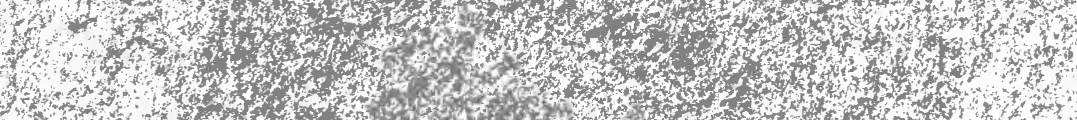

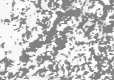

3
$m$

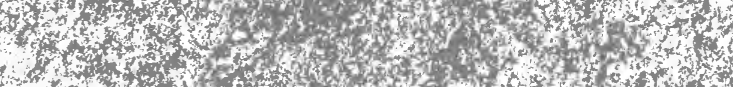

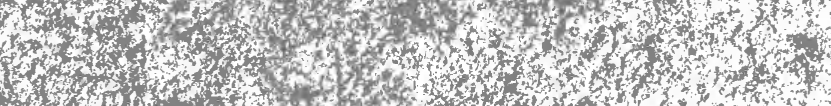

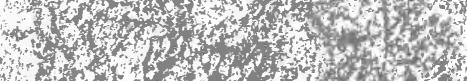

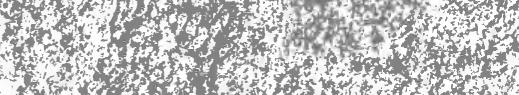

H.

H.t.

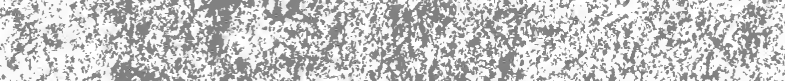

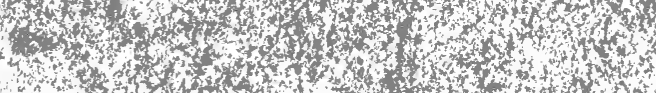

$\begin{array}{ccc}4 & \end{array}$

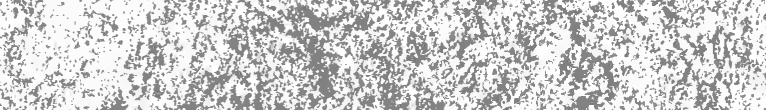

F,

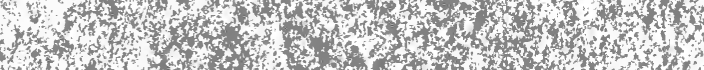

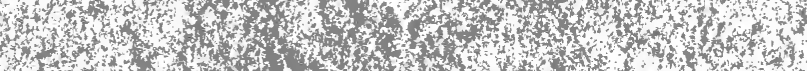

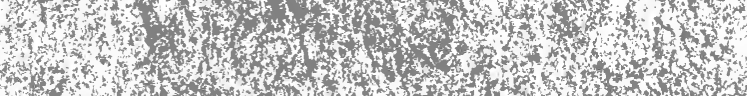

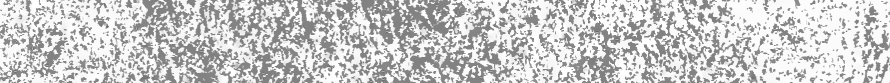

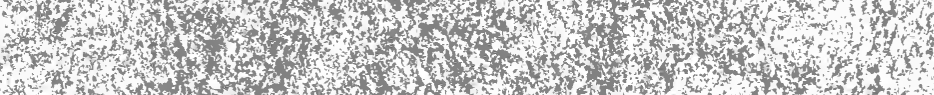

3.

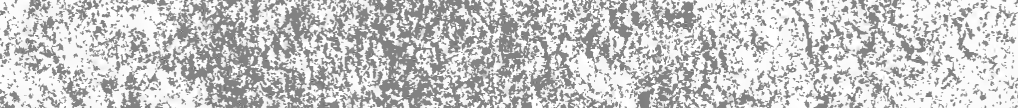

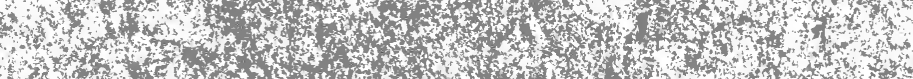

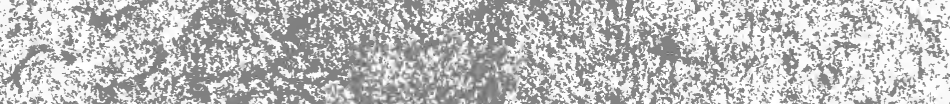

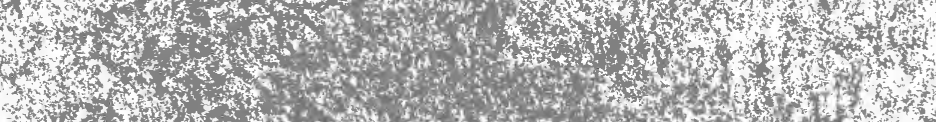

H.t. H.

3.

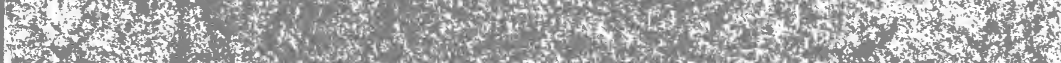

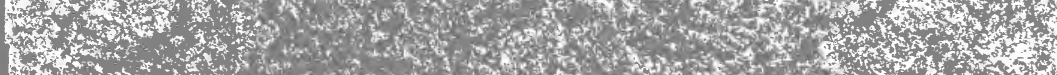


